\section{Çevresel Dinamizmin ve Çevresel Olumsuzluğun Düzenleyici Rolü Altında Tepe Yönetim Profilinin ve Firma Yapısının Sezgiye Dayalı Stratejik Karar Almaya Etkilerinin İncelenmesi ${ }^{1}$}

\author{
Fahriye Oben Uru ${ }^{\mathrm{a}}$, Mustafa Aslan ${ }^{\mathrm{b}}$
}

Öz: Bu çalışmanın amacı, çevresel dinamizmin ve çevresel olumsuzluğun düzenleyici rolü altında tepe yönetim profilinin ve firma yapısının, sezgiye dayalı stratejik karar almaya etkilerini ortaya koymaktır. Kolayda örnekleme yöntemi kullanarak 493 tepe yöneticisinden anket yöntemiyle veri toplanmıştır. Verilerin analizinde yapısal eşitlik modeli kullanılmıştır. Çalışmanın bulguları, tepe yönetimin eğitim düzeyinin ve sektör deneyiminin sezgiye dayalı stratejik karar almayı olumlu, yaşının ve kıdemin ise olumsuz yönde etkilediğini göstermektedir. Buna ilaveten, firma biçimselleşme derecesi ve cironun, sezgiye dayalı stratejik karar almayı olumsuz, çalışan sayısı ve firma yaşının ise olumlu yönde etkilediği tespit edilmiştir. Tepe yönetimin yaşının sezgiye dayalı stratejik karar almaya olumsuz etkisinin, çevresel dinamizm arttıkça zayıfladığı ve hatta bu etkinin olumluya döndüğü, buna karşın tepe yönetimin yaşının sezgiye dayalı stratejik karar almaya olumsuz etkisinin çevresel olumsuzluk arttıkça daha da güçlendiği görülmüştür. Ayrıca, ciro bazlı firma büyüklüğünün sezgiye dayalı stratejik karar almaya olumsuz etkisinin, çevresel dinamizm arttıkça daha da arttığı tespit edilmiştir. Ayrıca, tepe yönetimin sektör deneyiminin sezgiye dayalı stratejik karar almaya olumlu etkisinin, çevresel olumsuzluk arttıkça daha da güçlendiği görülmüştür.

\section{Investigation of the Effects of Top Management Profile and Firm Structure on Intuitive Strategic Decision-Making Under the Moderating Role of Environmental Dynamism and Environmental Hostility}

\begin{abstract}
The main goal of this study is to reveal the effects of the top management profile and firm structure on intuitive strategic decision-making under the moderating role of environmental dynamism and environmental hostility. Using the convenience sampling method, data were collected from 493 top managers via survey method. Structural equation modelling was used to analyze the data. The findings of this study show that the education level, and sector experience of top management affect intuitive strategic decision-making positively and while their age and tenure negatively affect it. In addition, it is determined that the formalization degree and revenue of the firm negatively affect intuitive strategic decision-making while the number of employees and firm age positively affect it. It is revealed that the negative effect of the age of the top management on the intuitive strategic decision-making weakens as the environmental dynamism increases and even this effect turns positive, whereas the negative effect of the age of the top management on the intuitive strategic decision-making gets stronger as the environmental hostility increases. Furthermore, the negative impact of revenue-based firm size on the intuitive strategic decision-making has been found to increase as environmental dynamism increases. Lastly, it is revealed that the positive impact of top management's sector experience on the intuitive strategic decision-making gets stronger as the environmental hostility increases.
\end{abstract}

Anahtar Sözcükler: Sezgiye Dayalı Stratejik Karar Alma, Tepe Yönetim, Firma Yapısı, Çevresel Dinamizm, Çevresel Olumsuzluk

JEL: M10, M19

$\begin{array}{ll}\text { Geliş } & : 24 \text { Ağustos } 2020 \\ \text { Düzeltme } & : 31 \text { Ekim 2020 } \\ \text { Kabul } & : 12 \text { Kasım 2020 } \\ & \\ \text { Tür } & : \text { Araştırma }\end{array}$

Keywords: Intuitive Strategic Decision-Making, Top Management, Firm Structure, Environmental Dynamism, Environmental Hostility

JEL: M10, M19

$\begin{array}{ll}\text { Received } & : 24 \text { August } 2020 \\ \text { Revised } & : 31 \text { October } 2020 \\ \text { Accepted } & : 12 \text { November } 2020 \\ \text { Type } & : \text { Research }\end{array}$

Cite this article as: Uru, F. O., \& Aslan, M. (2021). Çevresel dinamizmin ve çevresel olumsuzluğun düzenleyici rolü altında tepe yönetim profilinin ve firma yapısının sezgiye dayalı stratejik karar almaya etkilerinin incelenmesi. Business and Economics Research Journal, 12(1), 173-195. http://dx.doi.org/10.20409/berj.2021.317

a Assoc. Prof., PhD., Istanbul Arel University, Faculty of Economics and Administrative Sciences, Business Administration (English) Department, Istanbul, Turkiye, obenuru@arel.edu.tr (ORCID ID: 0000-0002-1960-5857)

b PhD., Istanbul Arel University, Faculty of Economics and Administration Sciences, Istanbul, Turkiye, maslan@hotmail.com (ORCID ID: 0000-0001-8049-3615) 


\section{Giriş}

Stratejik yönetim, stratejik karar almaya (SKA) dayanır. Firmanın kurulma kararından, faaliyet göstereceği alanın, vizyonunun, misyonunun ve hedeflerinin belirlenmesi ile bu hedefleri gerçekleştirecek stratejilerin seçimi tümüyle karar almadır. Bu nedenle yönetimin karar almaya; stratejik yönetimin de SKA'ya dayandığı belirtilebilir (Ürü Sanı, 2018a). Yazında stratejik karar alma sürecinin (SKAS) öncülleri olarak gösterilen, bu süreci etkileyen faktörler genelde "tepe yönetim", "çevresel koşullar", "firma yapısı" ve "kararın belirli özellikleri" olarak dört grupta sınıflandırılmaktadır (Papadakis vd., 1998; Elbanna ve Child, 2007; Nooraie, 2012; Shepherd, 2014; Shepherd ve Rudd, 2014; Elbanna ve Fadol, 2016; Ürü Sanı vd., 2016; Mehrotra ve Gopalan, 2017). Örgütün geleceğini yakından ilgilendirdiği için SKA, tepe yönetimin yerine getirdiği en temel ve can alıcı işlevdir. Yapı ve strateji arasındaki güçlü bağlar ve birbirlerini etkileme düzeyleri dikkate alındığında, sadece karar alıcıların profil özelliklerinin değil, firma yapısının da alınan stratejik kararlarda belirleyici olduğu söylenebilir.

Firmaların geleceklerini belirlemesi sebebiyle son derece önemli olan SKAS, birçok belirsizlikleri ve riskleri de barındırmaktadır (Ürü Sanı, 2018b). Bu belirsizlikler ve riskler, olumsuzluk ve dinamizmin hâkim olduğu çevresel koşullarda daha da artmaktadır. Stratejik karar alıcılar olan tepe yönetim, bu belirsizlikleri azaltmaya ve riskleri mümkün olduğunca bertaraf etmeye çalışsa da tepe yönetimin mevcut ve oluşabilecek problemleri her yönüyle, rasyonel bir şekilde kavrayabilmesi ve bu problemlere rasyonel çözüm alternatifleri geliştirebilmesi elde edebileceği enformasyonla sınırlıdır. Tepe yönetimin elde ettiği enformasyona dayanarak problemi kavraması, rasyonel çözümler üretmesi ve ürettiği çözümleri uygulayabilmesi deneyimi, eğitim düzeyi, bilişsel seviyesi ve firma yapısıyla sınırlıdır. Bu nedenle tepe yönetim sahip olduğu enformasyonun yanı sıra sezgilerini de kullanarak mevcut ve muhtemel sorunları anlamaya ve bunlara çözümler üreterek belirsizlikleri en aza indirgemeye çalışır. Yani her zaman için alınan stratejik kararlar az ya da çok tepe yönetimin sezgilerine dayanmaktadır.

Bu çalışmanın amacı, tepe yönetim profili ve firma yapısının, sezgiye dayalı SKA'ya etkilerini ve bu etkilerde çevresel dinamizmin ve olumsuzluğun olası düzenleyici rollerini ortaya koymaktır. Bu amaçla, çalışmamızda öncelikle tepe yönetim profili ardından firma yapısının sezgiye dayalı SKA ile ilişkileri ve bu ilişkilerde çevresel koşulların rolleri kuramsal çerçevede açıklanmış sonrasında bu kapsamda geliştirilen araştırma modelinin test edilmesiyle elde edilen bulgulara ilişkin sonuç ve tartışmaya yer verilmiştir.

\section{Kuramsal Çerçeve}

Çalışmanın bu bölümünde sezgiye dayalı SKA, tepe yönetim profili, firma yapısı, çevresel olumsuzluk ve çevresel dinamizm kavramları açıklanmaktadır.

\subsection{Sezgiye Dayalı Stratejik Karar Alma}

Sezgiye dayalı SKA kavramından önce sezgi kavramının mahiyetini açıklamak gerekir. Sezginin tam olarak ne olduğunun açıklanabilmesi için de öncelikle ne olmadığının netleştirilmesi gerekmektedir.

- Sezgi kişinin olacakları veya bir sonraki adımı tahmin etmesi değildir. Yarın havanın nasıl olacağının tahmin edilmesi veya bir sonraki yıl hangi üründen kaç tane satılabileceğinin tahmin edilmesi sezgi değildir.

- Olasılık hesaplarına dayanarak öngörüde bulunmak sezgi değildir.

- Usa vurum, mantık yürütmek sezgi değildir: "A firmasının uygulayacağı $x$ stratejisi karşısında B firması y stratejini uygular" veya "X hammaddesi yükselişi, talep artışı olacağından gelecek ay da devam edecek" çıkarımı sezgi değildir.

- Sezgi ilham veya kalbe vuku da değildir. Yani aniden, ortada hiçbir sebep yokken herhangi bir konuyla ilgili bir yargı veya kanı oluşması değildir.

- Sezgi öngörü değildir. "On yıl sonra elektrikli araçlar otomotiv piyasasını domine edecek" öngörüsü sezgi değildir. 
TDK'ya (2019) göre sezgi; "sezme yeteneği, feraset, gerçeğin deneye veya akla vurmadan doğrudan doğruya kavranması" olarak tanımlanmaktadır. Sezgi kavramı, sezginin öncelleri ve nasıl oluştuğu, kaynağı üzerinde filozoflar da tartışmışlardır. Bergson'a göre sezginin kaynağı içgüdüdür, Descartes ve Kant'a göre ise sezginin kaynağı akıldır ve sezgi ile zekâ birbirlerine taban tabana zıttır. Sezgi; hayatı, iç dünya ile bilimi gösterirken, zekâ; fizik dünyayı ve onunla ilgili bilimi göstermektedir (Öktem, 2000; Köz, 2005). Eflatun, insanın doğuştan doğrunun bilgisine hâkim olduğunu, sürekli iyiyi, doğruyu ve güzeli aradığını ve bulduğunda da özel bir sezgi ile o olduğunu kavradığını (Eflatun, 2017) ifade etmektedir. Diğer bir deyişle Eflatun sezgiyi; kişinin sahip olduğu bilgiyi, belli emarelerle karşılaştığında otomatik olarak, herhangi bir çaba harcamadan anımsaması şeklinde tanımlamaktadır.

Psikologlar ise sezgiyi bireyin mantıksal çıkarımlar ve olasılık hesaplarıyla sonuca gitmeye çalışması olarak değerlendirmişler ve dolayısıyla da irrasyonel ve güvenilmez olarak kabul etmişlerdir (Tversky ve Kahneman, 1974; Tura, 1996; Pretz, 2011). Baylor (2001) ise sezgiyi "mevcut ilişkiyi hemen yorumlayan otomatik bir davranış şekli" olarak tanımlamaktadır. Kontrollü düşünme süreci olan üstbilişin, eylem hakkında düşünmeye zorladığı için beyni özgür bırakmadığını ve bunun da doğrudan doğruya düşüncenin bir parçası olan sezgiye zarar verdiğini söylemektedir (Bkz. Şekil 1).

Şekil 1. Sezgi, Usavurma ve ilişkiler

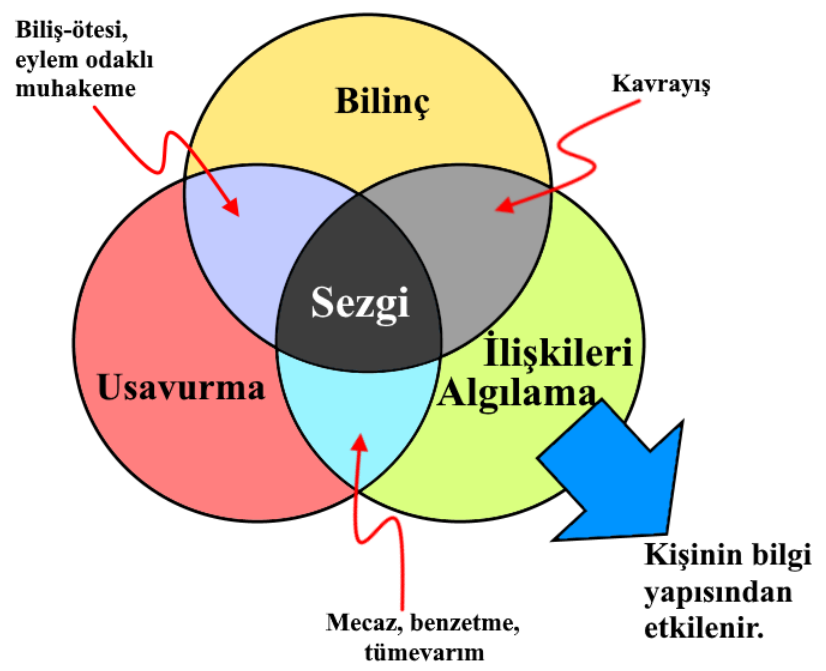

Kaynak: Baylor, 2001.

Yukarıdaki açıklamalardan yola çıkarak sezgi şu şekilde tanımlanabilir; uzman olunan veya aşina olunan bir konu, bir problem veya bir alanda insanların herhangi bir bilişsel (analitik neden-sonuç ilişkisi, irdeleme veya analiz) süreçlere başvurmadan bütünsel bir kavrayış ve anlayış ile çözüm üretebilmesi durumudur.

Çalışmalar, sezgiye dayalı alınan kararların bilinçli bir şekilde, analize dayalı alınmış olan kararlardan daha isabetli olduğunu göstermektedir (Dijksterhuis, 2004; Dijksterhuis ve Olden, 2006; Bos vd., 2008). Bunun sebebi de geçmişte bilinçdışı ve düzensiz bir şekilde elde edilmiş olan bilgi parçacıklarının birikimi ile alınan kararların daha isabetli hale gelmesidir (Lufityanto vd., 2016).

Sezgi ve SKA tanım ve açıklamalarından hareketle sezgiye dayalı SKA; karar alıcıların sahip oldukları tecrübe, sektörel bilgi, kültür, bilişsel farkındalık gibi farklı kişisel özelliklerini ve en önemlisi de profesyonel yargısını kullanarak alınan stratejik karara son şeklini vermesi (Simon, 1987) olarak tanımlanabilir. Bu bağlamda sezgi; kişinin bilişsel süreçleri kullanmadan, bütünsel bir kavrayış ile konu hakkında bir yargıya varmasıdır. Ya da Sinclair (2011)'in dediği gibi, nedenini ve nasılını bilmeden sadece çözümü bilmesidir. Başka bir deyişle kişinin mevcut ilişkiyi üzerinde çok fazla analiz yapmadan, bilişsel süreçleri kullanmadan hemen yorumladığı otomatik bir davranış şeklidir (Baylor, 2001). Çalışmalar tepe yöneticilerin aldıkları stratejik 
kararların çoğunun yüksek oranda sezgilerine dayandığını ortaya koymaktadır (Burke ve Miller, 1999; Emmanuel vd., 2010). Özellikle Emmanuel vd. (2010)'nin yaptıkları çalışma, İngiltere'de faaliyet gösteren firmalarda, karar alıcıların, stratejik yatırım kararı süreçlerinde sezgilerine çok güvenen deneyimli tepe yöneticiler olduklarını ortaya koymaktadır. Yine yapılan çalışmalar göstermektedir ki sezgiye dayalı alınan stratejik kararlar, analize dayandııımış, bilişsel süreçler kullanılarak alınmış olan kararlara kıyasla daha isabetli olmaktadır (Dijksterhuis, 2004; Dijksterhuis ve Olden, 2006; Bos vd., 2008). Bos vd. (2008) kişinin, sezgilerine dayanarak aldığı stratejik kararlarda bir amacının olması gerektiğini, ancak amaç olduğu taktirde sezginin alınan kararın isabetli olmasını olumlu yönde etkilediğini; Kahneman ve Klein (2009) ise sezgiye dayalı SKA'nın isabetliliğini, çevresel koşulların bilinirliğiyle ilgili olduğunu, sadece kişisel deneyimin kararın isabetliliğinin doğru bir göstergesi olmayacağını belirtmektedirler.

\subsection{Tepe Yönetim Profili}

Bireyin sahip olduğu temel niteliklerin bileşimi olarak tanımlanan profil özellikleri, kişilerin karar alma tarzlarına ve dolayısıyla da SKA'larına etki etmektedir (Hambrick ve Mason, 1984; Cannella ve Holcomb, 2005). Yaşar (2016), yöneticileri karar alma tarzında farklılığa neden olan profil özelliklerini yaş, eğitim düzeyi, görev unvanı ve kıdem olarak tanımlamaktadır.

SKAS'Iarına etki eden bazı profil değişkenleri tepe yönetimdeki kişilerin sayısı (Atuahene-Gima, 2004; Carmeli ve Schaubroeck 2006; Parayitam ve Pepenhausen, 2018), etnik köken (Slater vd., 2007), risk alma eşiği, sahip olunan hem dini hem de ahlaki değerler anlamında inanç, farklı pozisyon deneyimi, yaş (Alpkan, 2000; Atuahene-Gima, 2004; Mitchell vd., 2011), eğitim düzeyi (Alpkan, 2000; Shepherd ve Rudd, 2014), eğitim dalı (Alpkan, 2000), bilişsel seviyeleri (March ve Simon, 1958) ve cinsiyettir (Lechner ve Gudmundsson, 2014).

Tepe yönetim, aldığı stratejik kararlarla firma performansını ve dolayısıyla da geleceğini etkilemektedir (Child, 1972). Bu durum, Hambrick ve Mason (1984) tarafından, Tepe Yönetimi Teorisi (Upper Echelon Theory) adını alan bir kuramsal çerçeveye oturtulmuştur. Bu kuramsal çerçeve, firmanın tepe yöneticilerinin bilişsel seviyelerinin, tecrübelerinin, kişilik özelliklerinin, değerlerinin kısacası profilinin, firmanın aldığı stratejik kararları ve bunun sonucunda da performansını nasıl etkilediğini ve firma ya da daha geniş tabiriyle örgütün, nasıl tepe yöneticisinin değerlerinin ve inançlarının bir yansıması haline döndüğünü anlamamızı sağlamaktadır (Hambrick ve Mason, 1984; Cannella ve Holcomb, 2005). Bu çalışmada, Yaşar (2016)'ın belirttiği bu dört boyutun yanı sıra cinsiyet ve sektör deneyimi de tepe yönetim profili kapsamına eklenmiştir.

\subsubsection{Tepe Yönetimin Yaşı}

Yaş ile SKAS'ın hızı arasında negatif yönlü bir ilişki vardır. Yaş ilerledikçe SKAS'da yavaşlama, risk almaktan kaçınma (Francioni vd., 2015), yeniliklere uyum sağlamada yavaşlama ve özellikle yenilik yapabilme yeteneğinde azalma (Ağraş ve Kılınç, 2014; Francioni vd., 2015) görülmektedir. Yaş ile kişisel değerler de değişmektedir ki değerlerin karar alma süreçlerinde alternatifleri belirlemedeki etkisi (Harrison,1999) düşünüldüğünde, yaş, amaçların belirlenmesini ve bu amaçları gerçekleştirmek için alınan kararları etkilemektedir (Karabacak, 2010).

\subsubsection{Tepe Yönetimin Cinsiyeti}

Cinsiyet; karar alma tarzı, risk alma eğilimi, görev performansı, örgütsel bağlılık gibi birçok örgütsel değişkenlerle ilişkili bir kavramdır (Özmen vd., 2005). Bu açıdan birçok araştırmada da belirtildiği gibi cinsiyet, alınan stratejik kararlarda etkili olmaktadır (Lechner ve Gudmundsson, 2014). Çünkü karar alma tarzı, risk alma eğilimi SKA'ya doğrudan etki eden profil özelliklerindendir (Alpkan, 2000; Atuahene-Gima, 2004; Mitchell vd., 2011). Bununla birlikte bilişsel seviyenin sezgiye dayalı SKA'da sahip olduğu rol (Sarvan vd., 2003), cinsiyetler arasındaki bilişsel seviye farkı (Frederick, 2005) ve kadınların erkeklere nazaran daha az risk alması (Barber ve Odean, 2001; Terjesen ve Szerb, 2008), cinsiyetin sezgiye dayalı SKA'da önemli olması gerektiği sonucunu ortaya koymaktadır. 


\subsubsection{Tepe Yönetimin Eğitim Düzeyi}

Öğrenme iki şekilde olmaktadır (Duggan ve Mason, 2011): Kişiler ya bilfiil yaşayarak öğrenirler ki bunun hatırlanması çok hızıdır ya da başkalarının yaşadıklarından okuma, gözlem veya duyum ile öğrenirler ki bunda hatırlama nispeten daha yavaş olur. Sezginin de öğrenme ve öğrenilenlerin otomatik hatırlanması (Gordon ve Berger, 2003; Edelman, 2004;) olduğu göz önüne alındığında, eğitimin sezgiye dayalı SKA'da etkili olduğu sonucuna varılabilir. Çünkü aldıkları eğitimi gerçek dünya ile bağlantılı hale getirilen kişilerin karşılaştıkları problemleri çözmede, sezgilerine dayanarak aldıkları kararların, diğer kişilere göre daha isabetli oldukları gözlemlenmiştir (Quinn, 2004). Bu çerçevede, tepe yönetimin eğitim düzeyi ve eğitim dalı, aldığı stratejik kararı etkilemektedir (Tyler ve Steensma, 1998; Alpkan, 2000).

\subsubsection{Tepe Yönetimin Sektör Deneyimi}

Firmalar genelde farklı türde problemlerle karşı karşıya kaldıkları için bu değişkenlik arz eden problemlere ürettikleri çözümler de değişmektedir (Tekin ve Çiçek, 2005). Farklı sektör veya firma deneyimi, tepe yöneticinin farklı problemlerle karşılaşmış ve çözümüne katkıda bulunmuş olma veya en azından önceden çalıştığı firmalardaki mesai arkadaşlarının karşılaşmış olduğu problemlere ve ürettikleri çözümlere aşina olma durumunu da beraberinde getirmektedir.

Farklı sektör veya firma deneyimi olan bir tepe yönetici, sektör tecrübesi daha az olan bir tepe yöneticiye göre aşina olmadığı bir sorun ile karşılaştığında yapmaması gerekenleri daha net bilebilmektedir. Bu aşinalık veya ne yapmaması gerektiğini bilme, tepe yöneticinin sezgiye dayalı aldığı stratejik karar sayısını arttıracaktır. Sezgilerine dayanarak stratejik karar aldığı zaman da alınan kararın isabet oranı yükselecektir. Araştırmalar da işinde uzman olan, sektör deneyimi yüksek tepe yöneticinin önce sezgilerine dayanarak stratejik karar aldığı ve sonrasında analiz yaptığı yönündedir (Okoli ve Watt, 2018).

\subsubsection{Tepe Yönetimin Kıdemi}

Firmadaki çalışma süresi yani kıdem arttıkça tepe yönetici mevcut durumu korumaya, sorunların çözümünde daha az bilgi kaynaklarına başvurmaya ve bu kaynaklardan elde ettiği bilgileri daha çok filtrelemeye ama daha az analiz etmeye meyilli olmaktadır (Hambrick ve Fukutomi, 1991; Alpkan, 2000). Bu durum tepe yönetimde sezginin daha fazla kullanılmasına ve proje başarısına olumlu yönde katkı vermesine (Dayan ve Elbanna, 2011), tepe yöneticilerin daha mahir olmasına (Ferreira vd., 2014) ve firma ile davranışsal bütünleşmesine (Şimşek vd., 2005) neden olmaktadır.

Kıdem arttıkça tepe yönetici mesai arkadaşlarının yetkinliklerini, becerilerini, kimden neyi isteyebileceğini ve kimin neye muktedir olabileceğini, firmanın güçlü ve zayıf yanlarını, yetkinliklerini, sektörü, rakiplerini ve çevresel koşulların olası etkilerini çok daha iyi anlayabilecektir. Böylece tepe yönetimin artan kıdemi, onun sezgiye dayalı aldığı stratejik kararların sayısı ve isabet oranında olumlu bir etkiye neden olabilecektir. Bu açıklamalar ışığında ilk hipotezimiz aşağıdaki gibidir:

$\boldsymbol{H}_{1}$ : Tepe yönetim profili sezgiye dayalı SKA'yı anlamlı düzeyde etkiler.

$\left(\boldsymbol{H}_{1 a}\right)$ Tepe yönetimin yaşı sezgiye dayalı SKA'yı anlamlı ve olumsuz yönde etkiler.

Tepe yönetimin $\left(\boldsymbol{H}_{1 b}\right)$ cinsiyeti, $\left(\boldsymbol{H}_{1 c}\right)$ eğitim düzeyi, $\left(\boldsymbol{H}_{1 d}\right)$ sektör deneyimi, $\left(\boldsymbol{H}_{1 e}\right)$ kıdemi sezgiye dayalı SKA'yı anlamlı ve olumlu yönde etkiler.

\subsection{Firma Yapısı}

Taylor'ın 1911 yılında yayınladığı, "Bilimsel Yönetimin İlkeleri - The Principles of Scientific Management" adlı eserinden başlayarak Henri Fayol, Max Weber, Hawthorn, Woodward, Aston, Tavistock, Burns ve Stalker ile devam eden, birçok uygulamacı ve bilim insanının katkı verdiği araştırmaların ortak amacı, etkinlik ve verimliliği en üst düzeye çıkartacak örgüt yapısının bulunmasıydı (Akdemir, 2018). Bu araştırmalarda firma yapıları ile birçok örgütsel değişken, özellikle de performans arasındaki ilişkiler aydınlatılmaya çalışımıştır. 
Firma yapısı sadece örgütün yapısını gösteren şema değildir; aksine örgütü oluşturan tüm insanların, pozisyonların, prosedürlerin, süreçlerin, firmanın kültürünün, kullandığı teknolojinin ve bunlarla ilgili tüm unsurların bütünüdür. Aynı zamanda bu bütünü oluşturan tüm unsurların birlikte nasıl çalıştığını, birbirileriyle nasıl bir etkileşimde olduğunun, bilgi ve emir akışının nasıl gerçekleştiğini tanımlamaktadır (Hall ve Saias, 1980). Dolayısıyla firma yapısının, karar alıcıların mevcut kaynaklarla, geçerli koşullar ve belirlenen şartlarprosedürler ve süreçler-dâhilinde stratejik karar almalarını şekillendireceği öngörülebilir.

Bir firmanın yapısını belirleyen tüm bu unsurları yapısal unsurlar ve bağlamsal unsurlar olarak iki başlık altında toplamak mümkündür. Yapısal unsurlar olarak biçimselleşme düzeyi, bölümlere ayırma (departmanlaşma), emir-komuta birliği, merkezileşme derecesi, iş bölümü ve uzmanlaşma, kontrol alanı, örgüt kültürü, yetki ve sorumluluk denkliği sayılabilir. Bağlamsal unsurlar olarak da amaç-strateji, çevre, teknoloji, büyüklük ve yaş sayılabilir (Cingöz, 2018).

Bu çalışmada yaş, büyüklük, merkezileşme ve biçimselleşme dereceleri firma yapısının unsurları olarak analizlere dâhil edilmiştir.

\subsubsection{Firma Yaşı}

Mintzberg'e (2015) göre ".... firmalar yaşlandıkça, diğer tüm koşullar aynı kalmak şartıyla, işlerini tekrar ederler. Sonuçta bu daha tahmin edilebilir bir hale gelir...". Firma yaşı arttıkça tepe yöneticinin firma üzerindeki etkisi, genç olan firmalara göre daha az olmaktadır (Miller vd., 1986). Bir başka deyişle firma yaşı arttıkça tepe yönetimin aldığı stratejik kararlarda firma kaynaklı sınırlamalar artmaktadır. Çünkü firmanın yaşı ilerledikçe stratejik hedefler iyice içselleştirilmiş, bölümler bu hedefleri gerçekleştirme yönünde detaylandırılmış ve hedefleri de stratejik hedeflerle uyumlu hale getirilmiş olacaktır. Bunun yanı sıra koordinasyon ve iletişim düzeyi yükselmiş firmanın karar alma dâhil tüm süreçleri belli kurallara bağlanmış ve belli standartlara oturtulmuş olacaktır (Eren vd., 2000; Aslan, 2020). Yani firmanın biçimselleşme düzeyi firma yaşı arttıkça artmaktadır (Mintzberg, 2015). Böylece tepe yönetimin SKAS'da sezgilerine daha az ihtiyaç duyarak genellikle rasyonel SKA'ya yönelebilecekleri belirtilebilir.

\subsubsection{Firma Büyüklüğü}

Yazındaki çalışmaların çoğunda, firma büyüklüğü olarak çalışan sayısı kullanılırken, bu çalışmada firma büyüklüğünün göstergesi olarak hem çalışan sayısı hem de ciro kullanılmış ve her ikisi de ayrı değişkenler olarak analizlere dâhil edilmiştir.

Firma büyüklüğü ile biçimselleşme derecesi, rekabet gücü, kaynak kullanımı ve kaynaklara erişim imkanları arasında olumlu yönde bir ilişki mevcuttur (Acs ve Audretsch, 1987; Eren vd., 2000; Bayyurt, 2007). Bununla birlikte büyüklüğe bağlı olarak departmanlaşma ve uzmanlaşma artmaktadır (Khanwalla, 1977; Goubko ve Mishin, 2008; Mintzberg, 2015). Biçimselleşmenin artması ile her bir görevin noksansız ve her seferinde aynı şekilde icra edilmesini güvence altına almak adına süreçler standartlaştırılmakta, çalışanların davranışlarının belli kalıplara oturtulması için de yoğun eğitimler verilmektedir (Kotey ve Folker, 2007). Bu da firmaların büyüdükçe mekanikleşmesine ve SKAS'larında sezgiye daha az meyletmelerine sebep olabilecektir. Nitekim Papulova ve Gazova'nın (2016) bulgularına göre büyük firmalar, SKAS'larında hemen hemen hiç sezgi kullanmazken küçük firmalarda sezgiye dayalı SKA oldukça fazladır.

\subsubsection{Merkezileşme Derecesi}

Merkezileşme derecesi, karar alma süreçlerinde yetkinin belli kişilerde toplanma derecesi ve bu kişilerin karar alma süreçlerindeki gücünü ifade etmektedir (Wally ve Baum, 1994; Papadakis vd., 1998; Ürü Sanı vd., 2016). Bu tanımdan hareketle merkezileşme derecesi, firmadaki karar alma düzeylerinin ve karar alma süreçlerine katılım oranının bir göstergesidir (Ürü Sanı vd., 2016).

Merkezileşme derecesi SKAS çalışmalarında en çok araştırılan, üzerinde en çok durulan hususlardan biri olmuştur (Papadakis ve Barwise, 2002). Merkezileşme derecesi arttıkça firmalar daha kuralcı bir yapıya bürünmekte (Arslan, 2010) biçimselleşme düzeyi de aynı oranda artmaktadır (Demir, 2015). Bu durum 
kendisini SKAS'larda da göstererek SKAS'da rasyonellik artmaktadır (Demir, 2015; Demir ve Wolff, 2017). Bu çerçevede, merkezileşme derecesi yüksek firmaların sezgiye dayalı SKAS'larının azalması öngörülebilir.

\subsubsection{Biçimselleşme Derecesi}

Önceden tanımlanmış politikaların, iş tanımlarının, iş yapış şekillerinin, yönetsel planların ve benzeri unsurların varlığı ve kullanım derecesi olan biçimselleşme düzeyi (Miller vd., 1986; Ürü Sanı vd., 2016), aynı zamanda SKAS'lara da etki etmektedir. SKAS'lardaki biçimselleşme, örgütsel politikaların, kuralların ve planların ne ölçüde resmi olarak ve açıkça belirtildiği ile ilgilidir (Eisenhardt ve Bourgeois, 1988). Diğer bir ifadeyle biçimselleşme, alternatif eylem yollarının belirlenmesi dâhil tüm SKAS'lara yazılı prosedürlerin rehberlik etmesi, alınacak stratejik kararların resmî belgelerin ışı̆̆ı altında önceden belirlenen kriterlere ve tekniklere göre değerlendirilmesidir (Papadakis vd., 1998).

Biçimselleşme derecesinin yüksek olması, SKAS'larda hangi araçların, planların, kural veya prosedürlerin kullanılacağını, seçim kriterlerinin neler olacağını açık bir şekilde ve yazılı olarak gösterdiğinden (Alpkan ve Doğan, 2008; Demir, 2015), tepe yöneticilerin sezgisel değil de rasyonel SKA'ya meyletmesine neden olabilecektir. Yani biçimselleşme düzeyi yüksek firmaların, sezgiye dayalı SKAS'lara daha az başvurmaları beklenebilir. Bu bağlamda ikinci hipotezimiz firma yapısı ve sezgiye dayalı stratejik karar alma üzerinedir:

\section{$\boldsymbol{H}_{2}$ : Firma yapısı sezgiye dayalı SKA'yı anlamlı düzeyde etkiler.}

$\left(\boldsymbol{H}_{2 a}\right)$ Firma yaşı, $\left(\boldsymbol{H}_{2 b}\right)$ firma büyüklüğü, $\left(\boldsymbol{H}_{2 c}\right)$ merkezileşme derecesi, $\left(\boldsymbol{H}_{2 d}\right)$ biçimselleşme derecesi, sezgiye dayalı SKA'yı anlamlı ve olumsuz yönde etkiler.

\section{4. Çevresel Koşullar}

Merkezinde insanların davranışları, insanlar ve insanların kurdukları kurumlarla oluşturdukları sosyal topluluklar ve bunların aralarındaki ilişkileri inceleyen sosyal bilimlerin çevresel koşullardan etkilenmemesi olanaksızdır. Bundan dolayıdır ki sosyal bilimlere göre insanlar, karar alırlarken öncelikle dış etmenleri tasnif ederler (Sur, 1986).

Stratejik kararların firmanın dış çevredeki değişimlere uyum sağlama çabası (Papadakis ve Barwise, 2002; Ürü Sanı vd., 2016) olduğu göz önüne alındığında, SKAS'da çevrenin etkisinin fazla olduğu sonucuna varılabilir. Nitekim çalışmalar da çevrenin SKAS üzerindeki etkisinin yüksek olduğunu göstermektedir (Hannan ve Freeman, 1977; Aldrich, 1979; Fredrickson, 1984; Eisenhardt, 1989; Judge ve Miller, 1991; Papadakis vd., 1998; Burke ve Miller, 1999; Elbanna ve Child, 2007; Gu ve Xie, 2009; Nooraie, 2012; Patterson vd., 2013; Kaufmann vd., 2014; Shepherd, 2014; Shepherd ve Rudd, 2014; Elbanna ve Fadol, 2016; Ürü Sanı vd., 2016; Mehrotra ve Gopalan, 2017; Okoli ve Watt, 2018). Bu noktada belirleyici olan, çevre ile nasıl bir etkileşim içerisine girildiği ve bu etkileşim sonucunda karar alıcının iç dünyasında neyin vuku bulduğudur (Sinclair, 2011). Nitekim karar alıcının sahip olduğu mesleki deneyimin yanı sıra karar alma sürecinde dış çevreden algıladığı uyarıcılar, ipuçları ve onları yorumlaması aldığı kararlarda etkilidir (Okoli, Weller ve Watt, 2016).

Bu çalışma kapsamında çevresel koşullar olarak çevresel dinamizm ve çevresel olumsuzluk ele alınmıştır.

\subsection{1. Çevresel Dinamizm}

Çevresel dinamizm kısaca, firmanın içinde faaliyet gösterdiği ve pazarının bulunduğu çevredeki müşteri talepleri, teknoloji, rekabet yapısı, ekonomik, sosyal ve siyasi politikalardaki değişimlerin sıklığıdır (Ürü Sanı vd., 2016). Araştırmalar, çevresel dinamizmin hâkim olduğu ortamlarda tepe yönetimin, stratejik kararlarını daha çok sezgilerine dayandırdıklarını (Burke ve Miller, 1999; Khatri ve Ng, 2000; Gu ve Xie, 2009; Patterson vd., 2013; Kaufmann vd., 2014; Ürü Sanı vd., 2016) hatta çoğu zaman stratejik kararlarını önce sezgilerine daha sonra yaptıkları analizlere dayalı olarak aldıklarını göstermektedir (Okoli ve Watt, 2018). Bununla birlikte, çevresel dinamizmin yüksekliği ile rasyonel SKA arasında olumlu yönde bir ilişki olduğunu belirten çalışmalar da mevcuttur (Priem, Rasheed ve Kotulic, 1995). 
Çevresel dinamizm ile ilgili hipotezlerimiz şu şekildedir:

$\boldsymbol{H}_{3}$ : Çevresel dinamizm, tepe yönetim profili ile sezgiye dayalı SKA ilişkisinde düzenleyici rol üstlenir.

( $\left.\boldsymbol{H}_{3 a}\right)$ Çevresel dinamizm, tepe yönetimin yaşının sezgiye dayalı SKA'ya olumsuz etkisini azaltacaktır.

Çevresel dinamizm tepe yönetimin, $\left(\boldsymbol{H}_{3 b}\right)$ cinsiyetinin, $\left(\boldsymbol{H}_{3 c}\right)$ eğitim düzeyinin, $\left(\boldsymbol{H}_{3 d}\right)$ sektör deneyiminin ve $\left(\boldsymbol{H}_{3 e}\right)$ kıdeminin sezgiye dayalı SKA'ya olumlu etkilerini daha da attıracaktır.

$\boldsymbol{H}_{5}$ : Çevresel dinamizm, firma yapısı ile sezgiye dayalı SKA ilişkisinde düzenleyici rol üstlenir.

Çevresel dinamizm $\left(\boldsymbol{H}_{5 a}\right)$ firma yaşının, $\left(\boldsymbol{H}_{5 b}\right)$ firma büyüklüğünün, $\left(\boldsymbol{H}_{5 c}\right)$ merkezileşme derecesinin ve $\left(\boldsymbol{H}_{5 d}\right)$ biçimselleşme derecesinin sezgiye dayalı SKA'ya olumsuz etkilerini daha da arttıracaktır.

\subsection{2. Çevresel Olumsuzluk}

"Dış çevredeki yoğun ve şiddetli rekabet, istikrarsız sektör yapısı, pazar fırsatlarının azlığı, katı düzenleyici sınırlamalar, düşük kar marjlarının bulunduğu vb. çevresel ortamı ifade eden çevresel olumsuzluk" (Ürü Sanı vd., 2016:449), karar alıcıların rahatça karar almalarını sınırlandırmaktadır (Papadakis ve Barwise, 2002). Çevresel olumsuzluk aynı zamanda firmaların merkezileşme ve biçimselleşme derecelerinde de etkin rol oynamakta ve tepe yöneticilerin karar alma tarzlarında da etkili olmaktadır (Ürü Sanı vd., 2016).

Tepe yönetim üzerinde çevresel olumsuzluğun oluşturduğu baskının büyüklüğü, alınacak kararın arz ettiği önem, süre baskısı ve kısıtlılı̆ı nedeniyle eksik enformasyon veya enformasyon yeterli olsa dahi bunun yeterince analiz edilememesi sonucunda sınırlı sayıda alternatif oluşturulması, tepe yönetimin daha çok sezgilerine dayanarak SKA'sına neden olmaktadır. Buna karşın, tepe yönetimin yaşı arttıkça, olumsuz çevresel koşulların da etkisiyle sezgiye dayalı SKA'sı azalabilmekte çünkü tepe yönetimin risk alma isteği düşmektedir (Francioni vd., 2015). Buna ilaveten yazında tepe yönetimin, çevresel dinamizmde olduğu gibi, olumsuz çevresel koşullarda hem rasyonel (Goll ve Rasheed, 1997; Campos, Parellada, Valenzuela ve Rubio, 2015) hem de sezgiye dayalı SKA'ya meylettiklerini (Ali, Badir, Dost ve Afsar, 2016; Elbanna, Child ve Dayan, 2013; Elbanna ve Child, 2007) belirten çalışmalar mevcuttur. Bu bağlamda çevresel olumsuzlukla ilgili hipotezlerimiz şunlardır:

$\boldsymbol{H}_{4}$ : Çevresel olumsuzluk, tepe yönetim profili ile sezgiye dayalı SKA ilişkisinde düzenleyici rol üstlenir.

$\left(\boldsymbol{H}_{4 a}\right)$ Çevresel olumsuzluk, tepe yönetimin yaşının sezgiye dayalı SKA'ya olumsuz etkisini daha da arttıracaktır.

Çevresel olumsuzluk tepe yönetimin $\left(\boldsymbol{H}_{4 b}\right)$ cinsiyetinin, $\left(\boldsymbol{H}_{4 c}\right)$ eğitim düzeyinin, $\left(\boldsymbol{H}_{4 d}\right)$ sektör deneyiminin ve $\left(\boldsymbol{H}_{4 e}\right)$ kıdeminin sezgiye dayalı SKA'ya olumlu etkilerini daha da attıracaktır.

$H_{6}$ : Çevresel olumsuzluk, firma yapısı ile sezgiye dayalı SKA ilişkisinde düzenleyici rol üstlenir.

Çevresel olumsuzluk, $\left(\boldsymbol{H}_{6 a}\right)$ firma yaşının, $\left(\boldsymbol{H}_{6 b}\right)$ firma büyüklügünün, $\left(\boldsymbol{H}_{6 c}\right)$ merkezileşme derecesinin ve $\left(\boldsymbol{H}_{6 d}\right)$ biçimselleşme derecesinin sezgiye dayalı SKA'ya olumsuz etkilerini daha da arttıracaktır.

\section{Metodoloji}

\subsection{Araştırma Sorusu/Problemi ve Araştırmanın Amacı}

Araştırma sorusu "Tepe yönetim profili ve firma yapısı ile sezgiye dayalı SKA arasında bir ilişki var mıdır? Eğer var ise bu iki değişken sezgiye dayalı SKA'yı ne derece etkilemektedir ve bu ilişkide çevresel olumsuzluk ile çevresel dinamizm ne derece düzenleyici rol oynamaktadırlar?" Bu soruyu cevaplayarak, bu çalışmada tepe yönetim profili ve firma yapısının sezgiye dayalı SKAS'ına etkilerini, çevresel dinamizm ve çevresel olumsuzluğun düzenleyici rolü altında ortaya koyulması amaçlanmaktadır. Araştırmanın amacına yönelik olarak geliştirilen araştırma modeli Şekil 2' de verilmektedir. 
Şekil 1. Araştırma Modeli

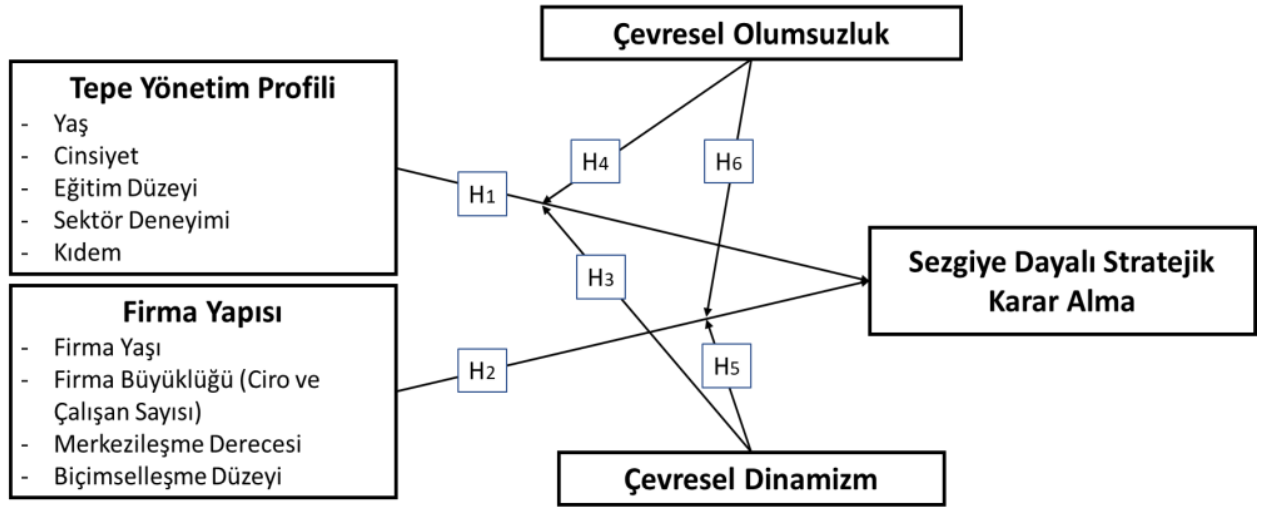

\subsection{Araştırmanın Yöntemi, Kapsamı ve Araçları}

Araştırma evreni, Türkiye'de hizmet sektöründe yer alan firmalar ve bunların tepe yönetimidir. Bu sektörün seçilmesinin nedeni; hizmet sektörü gibi emek yoğun sektörlerde tepe yönetim, rekabet avantajı elde edebilmek adına müşterilerin istek, beklenti ve taleplerine hızla cevap verebilecek nitelikte hatta beklentilerinin de ötesine geçebilecek özellikte hızlı ve isabetli SKA ve bu hususta sezgilerine meyletme durumunda olmalarıdır. Araştırma örneklemi ise, hizmet sektöründe yer alan turizm, sağlık, medya, bilişim ve bankacılık faaliyetlerine Türkiye genelinde devam eden, kolayda örnekleme yöntemiyle ulaşılan 549 firmanın tepe yöneticileridir. Bu kesitsel alan araştırmasında her firmadan bir tepe yönetici ile görüşülmüştür. Bu çerçevede, tepe yönetimle öncelikle telefonla iletişime geçilerek yüz yüze görüşme yöntemiyle mülakat yapılmış, kendilerinden son bir yıl içerisinde aldıkları kurumsal nitelikli stratejik kararları/stratejileri göz önüne alarak anket formlarını elektronik ortamda doldurmaları istenmiştir. Yazında bazı araştırmalar, örgütsel düzeyde SKA'yı analiz birimi olarak alırken, çalışmamızın konusu sezgiye dayalı SKA olduğu için ve sezginin de bireysel bir değişken olmasından mütevellit bu araştırmanın analiz birimi ilgili yazındaki ağırlığı oluşturan diğer araştırmalarda olduğu gibi bireysel stratejik karardır. Bu araştırma kapsamındaki veriler, katılımcılardan Temmuz-Kasım 2019 tarihleri arasında toplanmıştır. Toplam 549 katılımcıyla gerçekleştirilen araştırmada, 38 katılımcının cevap formu iç çelişkilerden, 5'nin mükerrer katılımından, 2 katılımcının ise stratejik kararlar üzerinde etkisi olmamasından, 11 katılımcının ise eksik cevap vermesinden dolayı bu anket formları analizlere dâhil edilmemiştir. Sonuç itibariyle, 493 katılımcıya ait anket formlarındaki veriler ile istatistiki analizler yapılmıştır. Katılımcıların anket formlarına verdikleri cevaplar kodlanmış ve kodlanmış verilerin SPSS programına aktarımı sağlanmıştır. Araştırmada, katıımcı profili ile firma büyüklüğü ve yaşını tespit etmek için demografik sorular sorulmuş, diğer değişkenlerin ölçümlenmesi için de 5 farklı ölçekten yararlanılmıştır. Anket formunun birinci bölümünde katılımcıların demografik özellikleri (Tepe Yönetim Profili) ile firma yaşı ve büyüklüğünü tespit etmeyi sağlayacak sorular sorulmuştur. İkinci bölümde ise Tablo 1 'de detayları verilmiş olan Hiyerarşik Merkezileşme Derecesi Ölçeği, Biçimselleşme Derecesi Ölçeği, Sezgiye Dayalı SKA Ölçeği, Çevresel Dinamizm Ölçeği ve Çevresel Olumsuzluk Ölçeği kullanılmıştır.

Tablo 1. Araştırmada Kullanılan Ölçme Araçları

\begin{tabular}{|l|l|c|}
\hline Ölçek & Alındığı Kaynak & ífade Sayısı \\
\hline Hiyerarşik Merkezileşme Derecesi & Ürü vd. (2011) & 5 madde \\
\hline Biçimselleşme Derecesi & Ürü vd. (2011) & 7 madde \\
\hline Sezgiye Dayalı SKA & Ürü Sanı vd. (2016) & 5 madde \\
\hline Çevresel Dinamizm & Ürü vd. (2011) & 5 madde \\
\hline Çevresel Olumsuzluk & Ürü Sanı vd. (2016) & 3 madde \\
\hline
\end{tabular}




\subsection{Verilerin Analizi}

Verilerin istatiksel analizleri SPSS 21.0 ve SmartPLS 3.2.8 istatistik paket programları ile yapılmıştır. Öncelikle katılımcılara ait demografik özellikler frekans analizi yapılarak tespit edilmiş, sonrasında ise araştırma modelinde yer alan değişkenlerin güvenilirliklerinin test edilmesi ve değişkenlere ait varsa alt boyutların tespiti için faktör analizi yapılmıştır. Faktör analizi sonucunda ortaya çıkan değişkenlerin alt boyutları arasındaki ilişkilerin tespitine yönelik korelasyon analizi ve araştırma hipotezlerinin test edilmesine yönelik yol analizleri yapılmıştır.

\section{Bulgular}

\subsection{Katılımcılar}

Araştırmaya katılan tepe yönetime ait demografik bilgiler toplu olarak Tablo 2'de verilmiştir. Tablo 2'ye göre, araştırmaya katılanların yaklaşık \%68'i 40 yaş ve üzerindedir ve $\% 71$ 'inden fazlası da 5 yıl ve üzeri sektör deneyimine sahiptir. Yine Tablo 2 incelendiğinde, katılımcıların tamamının görev unvanları itibarıyla stratejik karar almaya yetkili oldukları görülmektedir.

Tablo 2. Katılımcıların Demografik Özellikleri

\begin{tabular}{|c|c|c|c|}
\hline Değişken & Kategoriler & $f$ & $\%$ \\
\hline \multirow{2}{*}{ Cinsiyet } & Erkek & 380 & 77,1 \\
\hline & Kadın & 113 & 22,9 \\
\hline \multirow{9}{*}{ Yaş } & 0-30 Yaş Arası & 29 & 5,9 \\
\hline & 30 Yaş Üstü-35 Yaş Arası & 50 & 10,1 \\
\hline & 35 Yaş Üstü-40 Yaş Arası & 77 & 15,6 \\
\hline & 40 Yaş Üstü-45 Yaş Arası & 80 & 16,2 \\
\hline & 45 Yaş Üstü-50 Yaş Arası & 77 & 15,6 \\
\hline & 50 Yaş Üstü-55 Yaş Arası & 112 & 22,7 \\
\hline & 55 Yaş Üstü-60 Yaş Arası & 42 & 8,5 \\
\hline & 60 Yaş Üstü-65 Yaş Arası & 11 & 2,2 \\
\hline & 65 Yaş Üstü & 15 & 3,0 \\
\hline \multirow{5}{*}{ Eğitim Düzeyi } & Lise ve Altı & 22 & 4,5 \\
\hline & Ön Lisans & 34 & 6,9 \\
\hline & Lisans & 226 & 45,8 \\
\hline & Yüksek Lisans & 170 & 34,5 \\
\hline & Doktora & 41 & 8,3 \\
\hline \multirow{6}{*}{ Görev Unvanı } & Koordinatör/Direktör (CFO, & 90 & 18,3 \\
\hline & Fabrika/İşletme Müdürü & 146 & 29,6 \\
\hline & Genel Müdür/CEO & 69 & 14,0 \\
\hline & Bölge/Ülke Müdürü & 74 & 15,0 \\
\hline & Yönetim Kurulu Başkanı & 35 & 7,1 \\
\hline & Yönetim Kurulu/İcra Kurulu & 79 & 16,0 \\
\hline \multirow{6}{*}{ Kıdem } & $0-3$ Yıl Arası & 93 & 18,9 \\
\hline & 3 Yıl Üstü-5 Yıl Arası & 93 & 18,9 \\
\hline & 5 Yıl Üstü-10 Yıl Arası & 135 & 27,4 \\
\hline & 10 Yıl Üstü-15 Yıl Arası & 71 & 14,4 \\
\hline & 15 Yıl Üstü-20 Yıl Arası & 89 & 18,1 \\
\hline & 20 Yıl Üstü & 12 & 2,4 \\
\hline
\end{tabular}


Tablo 2. Katılımcıların Demografik Özellikleri

\begin{tabular}{|c|c|c|c|}
\hline Değişken & Kategoriler & $f$ & $\%$ \\
\hline \multirow{6}{*}{ Sektör Deneyimi } & 1 Yıl Üstü-3 Yıl Arası & 58 & 11,8 \\
\hline & 3 Yıl Üstü-5 Yıl Arası & 82 & 16,6 \\
\hline & 5 Yıl Üstü-10 Yıl Arası & 117 & 23,7 \\
\hline & 10 Yıl Üstü-15 Yıl Arası & 121 & 24,5 \\
\hline & 15 Yıl Üstü-20 Yıl Arası & 102 & 20,7 \\
\hline & 20 Yıl Üstü & 13 & 2,6 \\
\hline
\end{tabular}

f: Sıklık; \%: Yüzde Dağııımı N: 493

\section{2. Ölçeklerin Faktör Analizleri ve Güvenilirlikleri}

Ölçeklerin geçerlilik ve güvenilirlik analizleri hem SPSS 21.0 hem de SmartPLS 3.2.8 istatistik paket programları ile gerçekleştirilmiş olup bu kapsamda öncelikle Doğrulayıcı Faktör Analizi (DFA) çalışmaları gerçekleştirilmiş daha sonra faktörlerin iç tutarlılıklarını belirlemek amacıyla güvenilirlik analizleri yapılmıştır. Sonrasında ise yine SmartPLS 3.2.8 ile değişkenler analize dâhil edildiğinde, tüm değişkenlerin bir arada faktör yükleri kontrol edilmiştir. Araştırma kapsamında kullanılan tüm istatistiksel analizlerde anlamlılık düzeyi 0,05 olarak kabul edilmiş ve elde edilen tüm sonuçlar çift yönlü olarak sınanmıştır. Cronbach Alfa değerinin yorumlanmasında Tablo 3 kullanılmıştır (Kılıç, 2016).

Tablo 3. Cronbach Alfa Güvenilirlik Katsayıları ve Yorumlama

\begin{tabular}{|c|c|}
\hline Güvenilirlik katsayısı (Cronbach Alfa) & Yorum \\
\hline$\geq 0,9$ & Mükemmel \\
\hline $0,7 \leq \alpha<0,9$ & İyi \\
\hline $0,6 \leq \alpha<0,7$ & Kabul edilebilir \\
\hline $0,5 \leq \alpha<0,6$ & Zayıf \\
\hline$\alpha<0,5$ & Kabul edilemez \\
\hline
\end{tabular}

Araştırma modelinin yol analizine geçmeden önce Smart PLS 3.2.8 yazılımında, araştırmada yer alan yapıların geçerlilik ve güvenilirlik çalışmaları gerçekleştirilmiştir. Geçerlilik ve güvenilirlik çalışmaları kapsamında; iç tutarlılık güvenilirliği (internal consistency reliability), birleşme geçerliği (convergent validity) ve ayrışma geçerliliği (discriminant validity) değerlendirilmiştir.

İç tutarlılık güvenilirliği için Cronbach Alfa ve birleşik güvenilirlik (CR: Composite Reliability) katsayıları incelenmiştir. Birleşme geçerliliğinin tespitinde, faktör yükleri ile açıklanan ortalama varyans (AVE: Average Variance Extracted) değerleri kullanılmıştır. Faktör yüklerinin ve Cronbach Alfa ve birleşik güvenilirlik katsayılarının 0,70 ve üzeri, açıklanan ortalama varyans değerinin de 0,50 ve üzeri olarak gerçekleşmesi beklenmektedir (Fornell ve Larcker, 1981; Hair vd., 2006; Hair, vd. Sarstedt, 2014;). Hair vd. (2014)'ne göre faktör yükleri 0,708 ve üzeri olmalı; faktör yükü $0,40^{\prime}$ ın altında kalan ifadeler modelden çıkarılmalı, 0,40 ile 0,70 arasında olan ifadelerin AVE ya da CR değerleri eşik değerin altında ise bunlar ölçüm modelinden çıkarılmalıdır. Bu doğrultuda yapılan analizler sonucunda Hiyerarşik Merkezileşme ölçeğinin ilk ifadesi olan HM1'in faktör yükü 0,293 olduğu için bu ifade modelden çıkartılarak analiz tekrarlanmıştır. Yeniden yapılan analiz sonucunda Hiyerarşik Merkezileşme ölçeğine ait Cronbach Alfa değeri hariç tüm ölçeklerin istenilen değerlerde olduğu görülmüştür. Bu ölçeğin Cronbach Alfa değeri eşik değere yakın, CR ve AVE değerleri ise eşik değerin üzerinde olduğundan modelin yol analizine devam edilmiştir.

Şekil 2'de model üzerinde her bir ifadenin faktör yükü okların üzerinde gösterilmekte ve her bir ölçeğin Cronbach Alfa değerleri o gizil yapıyı temsil eden mavi dairenin içerisinde belirtilmektedir. Ayrıca Tablo 4'te de tüm ölçeklerin analiz sonuçları bir arada verilmektedir. 
Şekil 2. SmartPLS Yol Analiz Modeli

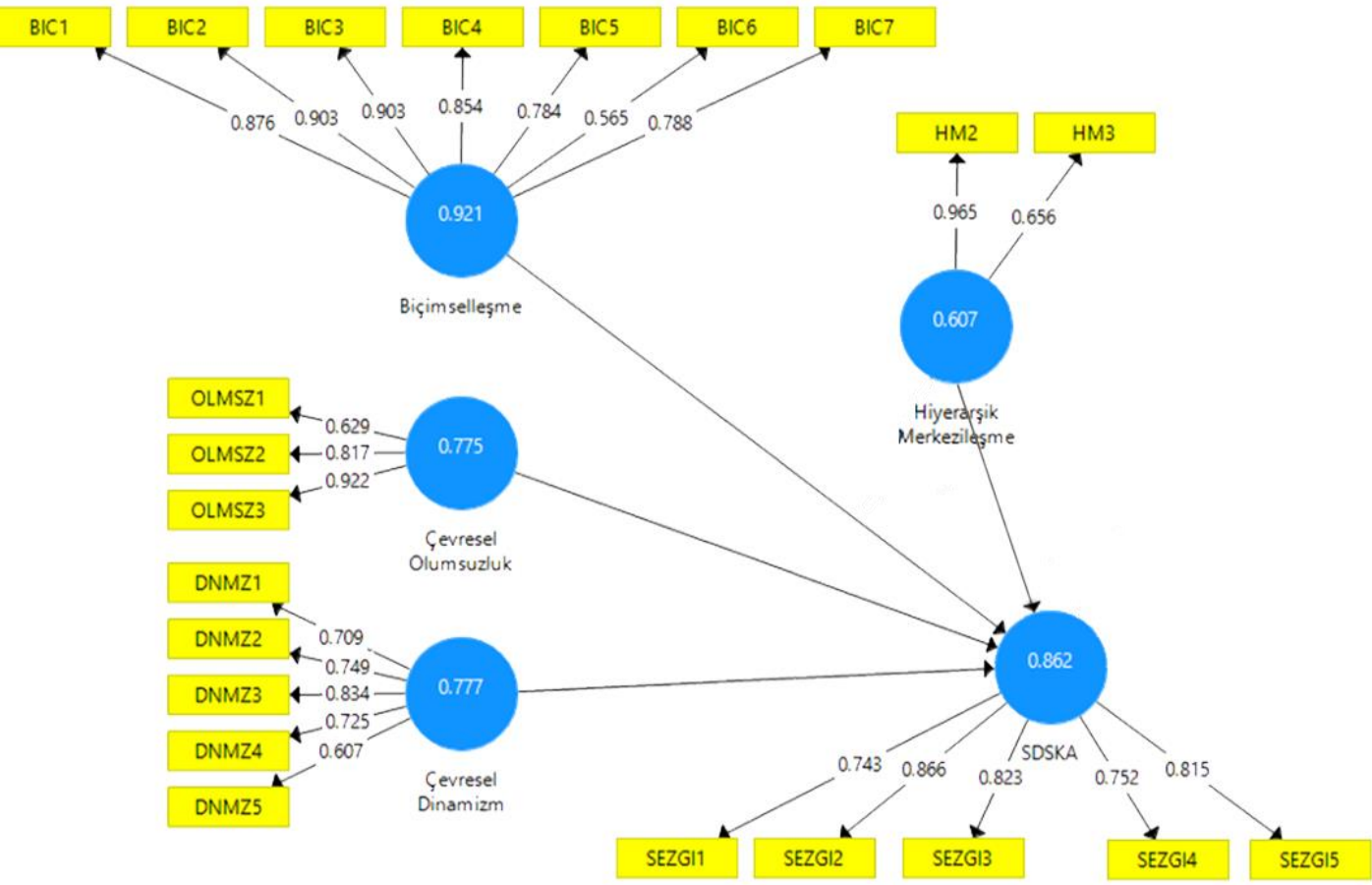

Tablo 4. Ölçüm Modeli Sonuçları

\begin{tabular}{|c|c|c|c|c|c|}
\hline Değişken & İade & Faktör Yükü & Cronbach Alfa & CR & AVE \\
\hline \multirow{7}{*}{ Biçimselleşme (BIC) } & $\mathrm{BIC1}$ & 0,876 & \multirow{7}{*}{0,921} & \multirow{7}{*}{0,933} & \multirow{7}{*}{0,669} \\
\hline & $\mathrm{BIC2}$ & 0,903 & & & \\
\hline & $\mathrm{BIC} 3$ & 0,903 & & & \\
\hline & BIC4 & 0,854 & & & \\
\hline & BIC5 & 0,784 & & & \\
\hline & BIC6 & 0,565 & & & \\
\hline & BIC7 & 0,788 & & & \\
\hline \multirow{5}{*}{ Çevresel Dinamizm (DNMZ) } & DNMZ1 & 0,709 & \multirow{5}{*}{0,777} & \multirow{5}{*}{0,848} & \multirow{5}{*}{0,531} \\
\hline & DNMZ2 & 0,749 & & & \\
\hline & DNMZ3 & 0,834 & & & \\
\hline & DNMZ4 & 0,725 & & & \\
\hline & DNMZ5 & 0,607 & & & \\
\hline \multirow{2}{*}{ Hiyerarşik Merkezileşme (HM) } & HM2 & 0,965 & \multirow{2}{*}{0,607} & \multirow{2}{*}{0,805} & \multirow{2}{*}{0,681} \\
\hline & $\mathrm{HM} 3$ & 0,656 & & & \\
\hline \multirow{3}{*}{ Çevresel Olumsuzluk (OLMSZ) } & OLMSZ1 & 0,629 & \multirow{3}{*}{0,775} & \multirow{3}{*}{0,838} & \multirow{3}{*}{0,638} \\
\hline & OLMSZ2 & 0,817 & & & \\
\hline & OLMSZ3 & 0,922 & & & \\
\hline \multirow{5}{*}{$\begin{array}{l}\text { Sezgiye Dayalı Stratejik Karar } \\
\text { Alma (SDSKA) }\end{array}$} & SEZGI1 & 0,743 & \multirow{5}{*}{0,862} & \multirow{5}{*}{0,899} & \multirow{5}{*}{0,642} \\
\hline & SEZGI2 & 0,866 & & & \\
\hline & SEZGI3 & 0,823 & & & \\
\hline & SEZGI4 & 0,752 & & & \\
\hline & SEZGI5 & 0,815 & & & \\
\hline
\end{tabular}


Yapıların, Hiyerarşik Merkezileşme Ölçeği hariç Cronbach Alfa katsayılarının 0,775 ile 0,921 arasında, CR katsayılarının da 0,805 ile 0,933 arasında olduğu görüldüğünden iç tutarlılık güvenilirliğinin sağlandığı söylenebilir. Tablo 4'teki değerler incelendiğinde, faktör yüklerinin 0,565 ile 0,965 arasında; AVE değerlerinin de 0,531 ile 0,681 arasında olması nedeniyle birleşme geçerliliğinin sağlandığı belirtilebilir.

Ayrışma geçerliliğinin tespiti için Fornell ve Larcker (1981) tarafından önerilen kriter ile Henseler, vd. (2015) tarafından önerilen HTMT kriterleri kullanılmıştır. Fornell ve Larcker (1981) kriterine göre, araştırmada yer alan yapıların açıklanan ortalama varyans (AVE) değerlerinin karekökü, araştırmada yer alan yapılar arasındaki korelasyonlardan yüksek olmalıdır. Tablo 5'te Fornell ve Larcker (1981) kriterine göre yapılan analiz sonuçları yer almaktadır.

Tablo 5. Ayrışma Geçerliliği Sonuçları (Fornell ve Larckell Kriteri)

\begin{tabular}{|l|c|c|c|c|c|}
\hline & BIC & KD & SDSKA & DNMZ & OLMSZ \\
\hline BIC & $\mathbf{( 0 , 8 1 8 )}$ & & & & \\
\hline KD & 0,432 & $\mathbf{( 0 . 9 0 7 )}$ & & & \\
\hline SDSKA & $-0,201$ & $-0,238$ & $\mathbf{( 0 , 8 0 1 )}$ & & \\
\hline DNMZ & 0,187 & 0,137 & 0,186 & $\mathbf{( 0 , 7 2 9 )}$ & \\
\hline OLMSZ & 0,103 & $-0,038$ & 0,224 & 0,383 & $\mathbf{( 0 , 7 9 9 )}$ \\
\hline
\end{tabular}

BIC: Biçimselleşme, HM: Hiyerarşik Merkezileşme, SDSKA: Sezgiye Dayalı Stratejik

Karar Alma, DNMZ: Çevresel Dinamizm, OLMSZ: Çevresel Olumsuzluk

Henseler vd. (2015)'nin kriterine göre HTMT (Heterotrait-Monotrait Ratio), araştırmada yer alan tüm değişkenlere ait ifadelerin korelasyonlarının ortalamasının (the heterotrait-heteromethod correlations) aynı değişkene ait ifadelerin korelasyonlarının (the monotrait-heteromethod correlations) geometrik ortalamalara oranlarını ifade etmektedir. Yazarlar HTMT değerinin; 0,90'nın, içerik olarak birbirine uzak kavramlarda ise $0,85^{\prime}$ in altında olması gerektiğini belirtmişlerdir. Tablo $6^{\prime}$ de de HTMT değerlerine yer verilmiştir.

Tablo 6. Ayrışma Geçerliliği Sonuçları (HTMT Kriteri)

\begin{tabular}{|l|c|c|c|c|c|}
\hline & BIC & HM & SDSKA & DNMZ & OLMSZ \\
\hline BIC & & & & & \\
\hline HM & 0,343 & & & & \\
\hline SDSKA & 0,191 & 0,129 & & & \\
\hline DNMZ & 0,238 & 0,166 & 0,233 & & \\
\hline OLMSZ & 0,207 & 0,085 & 0,203 & 0,538 & \\
\hline
\end{tabular}

BIC: Biçimselleşme, HM: Hiyerarşik Merkezileşme, SDSKA: Sezgiye Dayalı Stratejik Karar Alma, DNMZ: Çevresel Dinamizm, OLMSZ: Çevresel Olumsuzluk

Tablo 6'daki değerler incelendiğinde HTMT değerlerinin eşik değerin altında olduğu görülmektedir. Böylelikle, Tablo 5 ve Tablo 6 'daki bulgulara dayanarak ayrışma geçerliliğinin sağlandığı belirtilebilir.

VIF (Varyans Büyüme Faktörü) değerlerinin (bkz. Tablo 7) incelenmesi sonucunda, bu değerlerin 5 ve daha düşük olması nedeniyle değişkenler arasında çoklu doğrusallık olmadığı görülmektedir (Rahman vd., 2016). 
Tablo 7. Araştırma Modelindeki Değişkenlere Ait VIF Değerleri

\begin{tabular}{|l|c|}
\hline & Sezgiye Dayalı SKA \\
\hline Biçimselleşme & 1,426 \\
\hline Cinsiyet & 1,086 \\
\hline Ciro & 2,371 \\
\hline Eğitim Düzeyi & 1,043 \\
\hline Firma Yaşı & 1,601 \\
\hline Görev Unvanı & 1,312 \\
\hline Hiyerarşik Merkezileşme & 1,109 \\
\hline Kıdem & 3,600 \\
\hline Sektör Deneyimi & 3,602 \\
\hline Tepe Yönetimin Yaşı & 1,250 \\
\hline Çalışan Sayısı & 2,280 \\
\hline Çevresel Dinamizm & 1,243 \\
\hline Çevresel Olumsuzluk & 1,213 \\
\hline
\end{tabular}

\subsection{Araştırmanın Hipotezlerine illişkin Analizler}

Araştırmanın hipotezlerini test etmek amacıyla oluşturulan yapısal eşitlik modeli şekil 3'te gösterilmiştir.

Şekil 1. Hipotez Testlerine Iliş̧kin Yapısal Eşitlik Modeli

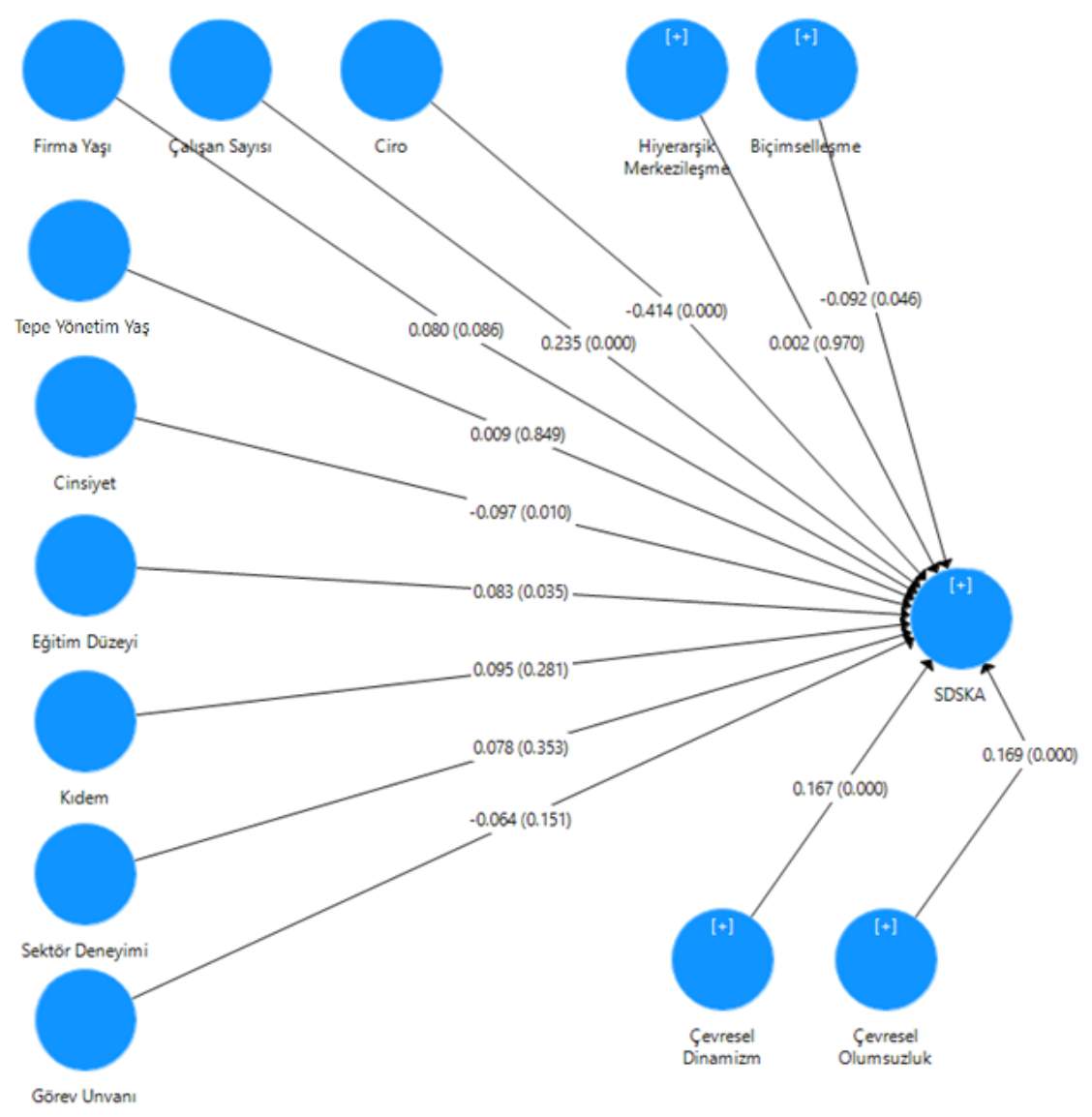


Araştırma modeli, SmartPLS 3.2.8 istatistik programı vasıtasıyla, kısmi en küçük kareler yol analizi (PLS-SEM) yöntemiyle test edilmiştir (Ringle vd., 2015). Yeniden örnekleme (bootstrapping) ile örneklemden 5000 alt örneklem alınarak t-değerleri hesaplanmıştır. Analiz sonuçlarından sadece istatistiki düzeyde anlamlı olanlar Tablo 8'de raporlanmıştır.

Tablo 8. Yapısal Eşitlik Modeli Analiz Sonuçları

\begin{tabular}{|l|c|c|c|c|c|}
\hline & $\boldsymbol{\beta}$ & $\boldsymbol{\varepsilon}$ & $\boldsymbol{\sigma}$ & $\mathbf{t}$ & $\mathbf{p}$ \\
\hline Biçimselleşme Düzeyi & $-0,093$ & $-0,100$ & 0,046 & 2,029 & 0,043 \\
\hline Cinsiyet & $-0,102$ & $-0,102$ & 0,037 & 2,781 & 0,005 \\
\hline Ciro & $-0,406$ & $-0,404$ & 0,053 & 7,726 & 0,000 \\
\hline Eğitim Düzeyi & 0,079 & 0,079 & 0,040 & 1,979 & 0,048 \\
\hline Firma Yaşı & 0,091 & 0,090 & 0,045 & 2,030 & 0,042 \\
\hline Sektör Deneyimi & 0,153 & 0,151 & 0,038 & 4,066 & 0,000 \\
\hline Tepe Yönetimin Yaşı & $-0,212$ & $-0,212$ & 0,078 & 2,718 & 0,008 \\
\hline Çalışan Sayısı & 0,246 & 0,246 & 0,054 & 4,524 & 0,000 \\
\hline Çevresel Dinamizm & 0,168 & 0,173 & 0,046 & 3,654 & 0,000 \\
\hline Çevresel Olumsuzluk & 0,176 & 0,180 & 0,042 & 4,187 & 0,000 \\
\hline
\end{tabular}

Sadece istatistiki düzeyde ilişkili değişkenlerin yer aldığı modelin bağımlı değişkeni açıklama düzeyi $\mathrm{R}^{2}$ $=0,264$ olarak tespit edilmiştir. Tablo 8'de verilen değerlere göre $H_{1}$ ve $H_{2}$ hipotezlerimiz kısmen doğrulanmıştır.

Sonrasında moderatör analizleri yapılmış ve Çevresel Dinamizmin, Ciro ve Tepe Yönetimin Yaşı ile Sezgiye Dayalı SKA arasındaki ilişkilerde düzenleyici rol oynadığı; Çevresel olumsuzluğun da sadece Tepe Yönetimin Yaşı ile Sezgiye Dayalı SKA arasındaki ilişkide düzenleyici rol oynadığı görülmüştür (bkz. Tablo 9).

Tablo 9. Moderatör ïlişkileri Eklenmiş Araştırma Modelinin Analiz Sonuçları

\begin{tabular}{|l|r|r|r|r|c|}
\hline Moderatör & \multicolumn{1}{|c|}{$\boldsymbol{\beta}$} & $\boldsymbol{\mu}$ & \multicolumn{1}{c|}{$\boldsymbol{\sigma}$} & \multicolumn{1}{c|}{$\mathbf{~}$} & \multicolumn{1}{c|}{$\mathbf{p}$} \\
\hline MOD: DNMZM - BD: Ciro & $-0,185$ & $-0,178$ & 0,060 & 3,058 & 0,002 \\
\hline MOD: DNMZM - BD: Tepe Yönetimin Yaşı & 0,095 & 0,092 & 0,046 & 2,061 & 0,040 \\
\hline MOD: OLMSZ - BD: Sektör Deneyimi & 0,089 & 0,086 & 0,044 & 2,004 & 0,045 \\
\hline MOD: OLMSZ - BD: Tepe Yönetimin Yaşı & $-0,134$ & $-0,132$ & 0,051 & 2,630 & 0,009 \\
\hline MOD: Moderatör; BD: Bağımsız Değisken
\end{tabular}

Bu sonuçlara göre $\mathrm{H}_{3}$ ve $\mathrm{H}_{4}$ hipotezlerimiz kısmen desteklenmektedir. Araştırma modelimizin moderatör ilişkileri eklenmiş son hali Şekil 4'te verilmektedir.

Şekil 4'te moderatörler eklenmiş araştırma modelimizin, Sezgiye Dayalı SKA'yı yaklaşık \%33'lük bir kısmını açıkladığı $\left(R^{2}=0,327\right)$ tespit edilmiştir. Modelimizdeki değişkenlerin bağımlı değişken üzerindeki etki büyüklükleri $\left(\mathrm{f}^{2}\right)$ ve yol katsayıları $(\beta)$ Tablo $10^{\prime}$ da verilmiştir. 
Şekil 4. Analiz Sonuçlarına Göre Araştırma Modeli

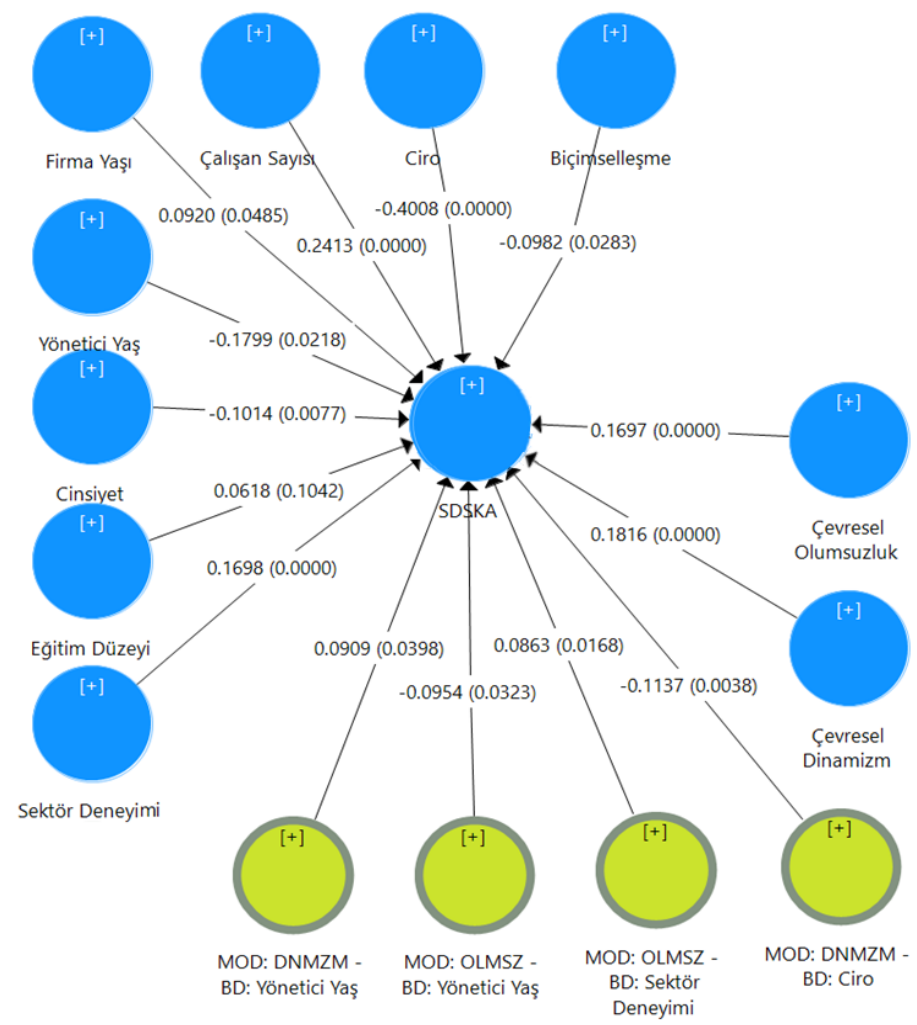

MOD: Moderatör, BD: Bağımsız Değişken, DNMZM: Çevresel Dinamizm, OLMSZ: Çevresel Olumsuzluk

Tablo 10. Etki Büyüklükleri $\left(\mathrm{f}^{2}\right)$ ve Yol Katsayıları $(\beta)$

\begin{tabular}{|l|c|c|c|}
\hline Değişken & $\mathbf{f}^{\mathbf{2}}$ & $\boldsymbol{\beta}$ & $\mathbf{p}$ \\
\hline Biçimselleşme & 0,011 & $-0,100$ & 0,043 \\
\hline Cinsiyet & 0,015 & $-0,104$ & 0,005 \\
\hline Ciro & 0,097 & $-0,391$ & 0,000 \\
\hline Eğitim Düzeyi & 0,006 & 0,066 & 0,048 \\
\hline Firma Yaşı & 0,008 & 0,093 & 0,042 \\
\hline MOD: DNMZM - BD: Ciro & $\mathbf{0 , 0 2 1}$ & $-0,121$ & 0,002 \\
\hline MOD: DNMZM - BD: Tepe Yönetimin Yaşı & 0,010 & 0,092 & 0,040 \\
\hline MOD: OLMSZ - BD: Sektör Deneyimi & 0,010 & 0,081 & 0,045 \\
\hline MOD: OLMSZ - BD: Tepe Yönetimin Yaşı & 0,011 & $-0,097$ & 0,009 \\
\hline Sektör Deneyimi & $\mathbf{0 , 0 3 7}$ & 0,164 & 0,000 \\
\hline Tepe Yönetimin Yaşı & 0,012 & $-0,185$ & 0,008 \\
\hline Çalışan Sayısı & $\mathbf{0 , 0 3 3}$ & 0,225 & 0,000 \\
\hline Çevresel Dinamizm & $\mathbf{0 , 0 3 1}$ & 0,166 & 0,000 \\
\hline Çevresel Olumsuzluk & $\mathbf{0 , 0 3 6}$ & 0,176 & 0,000 \\
\hline
\end{tabular}

MOD: Moderatör, BD: Bağımsız Değişken, DNMZM: Çevresel Dinamizm,

OLMSZ: Çevresel Olumsuzluk

Tablo $10^{\prime}$ da verilen $\mathrm{f}^{2}$ etki büyüklüğü değerlerine bakıldığında en yüksek etkinin ciro sonra sırasıyla sektör deneyimi, çevresel olumsuzluk, çalışan sayısı ve çevresel dinamizmden kaynaklandığı görülmektedir. Firma büyüklügünün göstergelerinden biri olarak aldığımız Ciro $(\beta=-0,391)$ beklendiği gibi Sezgiye Dayalı SKA'yı olumsuz yönde etkilemekte, tepe yönetimin karar alma süreçlerinde sezgi kullanımını azaltmaktadır. 
Yani firma ciro bazlı büyüdükçe tepe yönetim daha az sezgiye dayalı SKA'tadır. Buna ilaveten, ciro bazlı firma büyüklüğünün sezgiye dayalı SKA üzerindeki etkisinde çevresel dinamizmin düzenleyici rolünün sezgiye dayalı stratejik karar almaya olan etkisi ise en düşük seviyededir.

Benzer şekilde Cinsiyet, Biçimselleşme ve Tepe Yönetimin Yaşının da katsayıları negatif olup Sezgiye Dayalı SKA'yı olumsuz yönde etkilemektedir. Etki büyüklüğü sırasına göre Çalışan Sektör Deneyimi, Çalışan Sayısı, Firma Yaşı ve Eğitim Düzeyi Sezgiye Dayalı SKA'yı olumlu yönde etkilemekte, tepe yönetimin SKAS'larında sezgi kullanımını arttırmaktadır.

Çevresel dinamizm artması, tepe yönetimin yaşının sezgiye dayalı SKA üzerindeki olumsuz etkisini azaltmakta ve çevresel dinamizm arttıkça sezgiye dayalı SKA'tan imtina eden tepe yönetimin dahi sezgiye dayalı SKA'ya meyletmesine neden olmaktadır. Bir başka deyişle daha dinamik çevresel koşullarda tepe yönetimin yaşı artııça, sezgiye dayalı SKA'ları daha da artmaktadır. Fakat çevresel dinamizm, firma büyüklüğünün (Ciro olarak) sezgiye dayalı SKAS'ları üzerindeki olumsuz etkilerini daha da güçlendirmekte ve tepe yönetimin sezgilerine başvurma eğilimlerini daha da azaltmaktadır. Çevresel olumsuzluğun artması ise tepe yönetimin yaşının sezgiye dayalı SKA üzerindeki olumsuz etkisini daha da güçlendirmekte ve olumsuzluk arttıkça tepe yönetimin yaşının ilerlemesiyle bağlantılı olarak sezgiye dayalı SKAS'lara meyletmeleri de azalmaktadır. Sektör deneyimi yüksek olan tepe yönetimin ise çevresel olumsuzluk arttıkça, sezgiye dayalı SKA'sı daha da artmaktadır.

\section{Sonuç ve Değerlendirme}

Sezgiye dayalı SKA sürecine etki eden unsurları ve etki düzeylerini ortaya koymaya çalışan bu çalışma, diğer birçok çalışmada olduğu gibi cinsiyetin karar almaya etkisi olduğunu, erkeklerin kadınlara oranla daha fazla sezgiye dayalı SKA'larını ortaya koymuştur. Bu durum kadınların daha korumacı ve riskten mümkün olduğunca kaçınmaya çalışmasından, erkeklerin iş hayatında bulunma sürelerinin kadınlara nazaran daha uzun süreli olmasından ve bu süre zarfında diğer yöneticilerle etkileşimlerinde birbirlerine aktardıkları bilgi ve tecrübeden kaynaklanabilir.

Tepe yönetimin eğitim düzeyinin ve sektör deneyiminin, sezgiye dayalı SKA'yı olumlu yönde etkilemesinin yani sezgiye dayalı SKA'yı arttırmasının altında yatan sebep de sezgilerin normalde öğrenme ve bu öğrenilenlerin otomatik olarak hatırlanmasından kaynaklanabilir. Tepe yönetimin eğitim düzeyi ve sektör deneyimi arttıkça bilgi ve deneyimleri artmakta, bu da tepe yönetimin sezgilerinin daha da keskinleşmesine sebep olabilmektedir.

Çevresel olumsuzluk arttıkça, tepe yönetimin sektör deneyimi sezgiye dayalı SKA'yı daha da attırmaktadır. Bunun sebebi de sektör deneyimi yüksek olan tepe yönetimin bilgiye erişimin zor, bilgi kaynaklarının sınırlı ve erişilen bilginin yetersiz, analiz için gerekli olan zamanın kısıtlı veya analiz yapmanın çok zor ya da imkânsız olduğu durumlarda, geçmişteki deneyimlerinden yola çıkarak, o deneyimlerini referans alarak sezgiye dayalı SKA'ları olabilir. Yazında da benzer yönde tespitler vardır ve çevresel olumsuzluğun yüksek olduğu pazarlarda deneyimli tepe yönetimin sezgilerine dayanarak SKA'larına işaret edilmektedir.

Tepe yönetimin yaşının sezgiye dayalı SKA'yı azaltması, çevresel olumsuzluğun artması ile daha da güçlenmektedir. Bunun nedeni ise olumsuz çevresel koşullarda tepe yönetimin yaşı arttıkça risk almada isteksizlik, daha güvenli adım atma zorunluluğunun hissedilmesi, hatalı karar alındığında çoğu şeyin kaybedilebileceği düşüncesi olabilir. Ihtiyar heyeti veya ihtiyari akçe gibi kavramlar ve aynı zamanda yaşlı kavramıyla eş anlamlı kullanılan ihtiyar kelimesinin gerçek anlamının yaşı değil tedbirli olduğu göz önüne alındığında, aslında tedbirli olma, riskten kaçınma durumunun yaş ilerledikçe arttığı belirtilebilir. Buna karşın, tepe yönetimin yaşının sezgiye dayalı SKA'yı azaltması, çevresel dinamizmin artması ile azalmakta ve sezgilerine dayanarak SKA'tan imtina eden tepe yönetimin dâhi sezgilerine başvurma düzeylerini arttırmaktadır. Bunun en büyük sebeplerinden biri, dinamizmin yüksek olduğu pazarlarda veya hızla değişen durumlar karşısında tepe yönetimin yaşı ilerledikçe elde ettiği deneyimle sezgilerine güvenerek aldığı stratejik kararlarla fırsatları ivedilikle ve isabetle değerlendirebileceğine olan inancı söz konusu olabilir. Bu durum, çevresel dinamizmin hâkim olduğu çevrelerde, stratejik kararların daha çok sezgiye dayalı alındığını, hatta 
çoğunlukla önce sezgiye dayalı stratejik kararların alındığı ve sonrasında analiz yapıldığı yönündeki ilgili yazını destekler niteliktedir.

Analiz sonuçlarına göre firma biçimselleşme düzeyi arttıkça, tepe yönetimin sezgiye dayalı SKA'sı azalmaktadır ki bu da ilgili yazın ile paralellik göstermektedir. Bunun sebebi de firmaların geçmiş tecrübelerinden elde ettikleriyle meydana getirdikleri kurallar bütününün bir parçası olarak SKAS'ların nasıl yürütüleceği de açık ve yazılı bir şekilde uygulanabilmektedir. Bu durum da tepe yönetimin sezgilerine dayalı SKA'sının önünde engel oluşturabilmekte ve onları rasyonel SKAS'lara yönlendirebilmektedir.

Yazında biçimselleşme düzeylerinin firmaların büyüklüğüyle doğru orantılı olduğu, firma büyüdükçe biçimselleşme düzeylerinin de arttığı belirtilmektedir. Bir başka ifadeyle, firma büyüklüğünün biçimselleşme düzeyini arttırması dolayısıyla da sezgiye dayalı SKA'yı azaltması beklenebilir. Bu durum firma büyüklüğü kıstası olarak ciro alındığında gerçekleşmektedir. Yani ciro arttıkça tepe yönetimin sezgiye dayalı SKA'sı azalmaktadır. Fakat çalışan sayısı firma büyüklüğünde belirleyici kriter olarak ele alındığında, önceki araştırmalar tarafından desteklenmeyen bir sonuç ortaya çıkmaktadır. Yani çalışan sayısı arttıkça tepe yönetimin sezgiye dayalı SKA'sı artmaktadır. Bunun nedeni, çalışan sayısının yüksek olduğu emek yoğun bir sektörde faaliyet gösterildiğinin; bu tip sektörlerin de genelde hizmet sektörleri olması sebebiyle değişen müşteri taleplerinin etkili biçimde karşılanmasına yönelik gerçekleştirilecek yenilikçi uygulama, yöntem ve süreçlere dönük stratejik kararlarda genelde sezgilerin kullanılması olabilir. İrrasyonel olan insan davranışları, müşteri istek, ihtiyaç ve beklentileri formülüze edilemediğinden, emek yoğun hizmet sektörlerinde sezgiye dayalı stratejik karar alma ön plana çıkabilmektedir. Bu sonucun yazınla çelişmediği, yazındaki bir boşluğu doldurarak katkıda bulunduğu belirtilebilir.

Firma yaşı ile ilgili elde ettiğimiz bulgular yazınla paralellik göstermemektedir. İlgili yazında firma yaşı arttıkça tepe yönetimin sezgiye dayalı SKA'sının azaldığı ifade edilirken araştırma bulgularımızda arttığı görülmektedir. Araştırmamızdaki katılımcıların ve çalıştıkları firmaların yaşlarıyla kıdemleri göz önüne alındığında, bu durumu üç olası şekilde açıklayabiliriz: (i) Araştırma kapsamındaki firmaların yaşı yazını bu konuda destekleyecek derecede ileri değildir. (ii) Katıımcıların çoğunun kıdemi 5 yıl, üçte birinden fazlasının kıdemi de 10 yıldan fazla olduğundan biçimselleşme süreçlerini gerçekleştiren yani kuralları koyan insanlar olma ihtimalleri yüksektir ve bu kuralı kendileri koydukları için de istedikleri gibi esnetebilmektedirler. (iii) Son olası durum olarak da yazında bu konuda bir boşluk olduğu ve çalışmamızla bu boşluğun giderildiği şeklindedir.

Hiyerarşik merkezileşmenin sezgiye dayalı SKA'ya etkisini öngören hipotezimiz yanlışlandığı halde sezgiye dayalı SKA'ya biçimselleşme üzerinden güçlü bir etkisi olduğu tespit edilmiştir. Dolayısıyla hiyerarşik merkezileşme ve SKA ile ilgili yapılacak olan çalışmalarda, hiyerarşik merkezileşmenin biçimselleşme üzerinden stratejik kararı etkileyecek şekilde araştırma modeline dâhil edilmesi gerektiği belirtilebilir.

$\mathrm{Bu}$ araştırmanın yazına kuramsal katkısı olarak özelde sezgiye dayalı SKA genelde ise firma büyüklüğünün bağımsız değişken olarak ele alındığı çalışmalarda, firma büyüklüğünün sadece ciro ya da çalışan sayısı olarak ele alınmaması, aksine her ikisinin de de ayrı ayrı araştırılması gerektiğinin bu çalışma ile ortaya koyulduğu belirtilebilir.

Araştırmanın yöneticilere ilişkin sonuçları kapsamında, tepe yönetimin eğitim düzeyinin yükseltilmesi; tepe yönetimde yer alacak genç yönetici adaylarının, mevcut tepe yönetim ile daha yakın mesai geçirmelerinin sağlanması ve bu kişilerin farklı stratejik kararların alınarak sonuçlarının asıl amaç ile kıyaslandığı eğitimlere katılmalarının sağlanıp böylece alacakları stratejik kararların kalitesini arttırması gerektiği ifade edilebilir.

Bu çalışmanın bazı kısıtları da mevcuttur. Araştırma için gerekli olan veriler tepe yönetimin kendisinden yani tek bir kaynaktan toplanmış ve değerlendirilmiştir. Dolayısıyla da bu değerlendirme şekli özneldir. Bu çalışmanın bir diğer kısıtı da bu çalışmada tepe yönetimin stratejik kararlar konusunda genel kanısı ölçülmüştür. Her farklı stratejik karar ve kararın nev'ine bağlı olarak tepe yönetimin karar alma şekli değişebilecektir. Kurumsal stratejiler, rekabet stratejileri veya fonksiyonel stratejileri ilgilendiren konularda tepe yönetimin yaklaşımı farklı olabilmektedir. Bu stratejilerde alınan kararların nev'ine, etkisine, stratejik 
kararı uygulamak için ihtiyaç duyulan kaynağın büyüklüğü ve benzeri hususlar da tepe yönetimin SKA şeklini, karar alma ve değerlendirme kıstaslarını değiştirecektir. Dolayısıyla bu kısıtlar da dikkate alındığında bunları ortadan kaldırmak adına gelecek çalışmalarda çevresel türbülans, karmaşıklık gibi farklı bağlamsal faktörler de modele dâhil edilerek boylamsal araştırma veya örnek olay çalışmaları yapılabilir.

\section{Beyan ve Açıklamalar (Disclosure Statements)}

1. Bu çalışmanın yazarları, araştırma ve yayın etiği ilkelerine uyduklarını kabul etmektedirler (The authors of this article confirm that their work complies with the principles of research and publication ethics).

2. Yazarlar tarafından herhangi bir çıkar çatışması beyan edilmemiştir (No potential conflict of interest was reported by the authors).

3. Bu çalışma, intihal tarama programı kullanılarak intihal taramasından geçirilmiştir (This article was screened for potential plagiarism using a plagiarism screening program).

\section{Son Notlar}

1. Bu makale Doç. Dr. F. Oben ÜRÜ’nün danışmanlığını yaptığı Mustafa Aslan'ın “Tepe Yönetimin Profili ve Firma Yapısının Sezgiye Dayalı Stratejik Karar Almaya Etkilerinin Farklı Sektörlerde Incelenmesi" adlı doktora tezinden türetilmiştir.

\section{Kaynaklar}

Acs, Z. J., \& Audretsch, D. B. (1987). Innovation, market structure, and firm size. The Review of Economics and Statistics, 69(4), 567-574.

Ağraş, S., \& Kılınç, í. (2014). Örgütsel yeteneklerin Türkiye'deki otel işletmeleri bağlamında analizi. Manas Sosyal Araştırmalar Dergisi, 3(4), 1-35.

Akdemir, A. (2018). Örgütlerin yönetimi: Kavramsal-kuramsal, tematik ve kurumsal açılardan yönetim (Ed.). İstanbul: Beta Yayınları.

Aldrich, H. E. (1979). Organizations and environments. Englewood Cliffs, NJ: Prentice-Hall.

Ali, Z., Badir, Y. F., Dost, M., \& Afsar, B. (2016). The dynamics of expert and team intuition in NPD projects: The role of environmental turbulence and expert power. The Journal of High Technology Management Research, 27(1), 1020.

Alpkan, L. (2000). Stratejik yönetimin kapsamlılığı, stratejik tercihler ve yönetici özellikleri arasındaki ilişkiler. Gebze Yüksek Teknoloji Enstitüsü Sosyal Bilimler Enstitüsü İ̧̧letme Anabilim Dalı, Yayınlanmamış Doktora Tezi, Gebze.

Alpkan, L., \& Doğan, T. (2008). Stratejik planlama süreci bileşenlerinin firma performansına etkileri. Kocaeli Üniversitesi Sosyal Bilimler Enstitüsü Dergisi, 16(2), 21-47.

Arslan, N. T. (2010). Klasik-neo klasik dönüşüm süreci: Yeni kamu yönetimi. C.Ü. Iktisadi ve Idari Bilimler Dergisi, 11(2), 21-38.

Aslan, M. (2020). Tepe yönetimin profili ve firma yapısının sezgiye dayalı stratejik karar almaya etkilerinin farklı sektörlerde incelenmesi. İstanbul Arel Üniversitesi, Sosyal Bilimler Enstitüsü, Yayınlanmamış Doktora Tezi, istanbul.

Atuahene-Gima, K., \& Li, H. (2004). Strategic decision comprehensiveness and new product development outcomes in new technology ventures. Academy of Management Journal, 47(4), 583-597.

Barber, B. M., \& Odean, T. (2001). Boys will be boys: Gender, overconfidence, and common stock investment. The Quarterly Journal of Economics, 116(1), 261-292.

Baylor, A. L. (2001). A U- shaped model for the development of intuition by level of expertise. New Ideas in Psychology, $19,237-244$.

Bayyurt, N. (2007). İşletmelerde performans değerlendirmenin önemi ve performans göstergeleri arasındaki ilişkiler. Journal of Social Policy Conferences, 53, 577-592. 
Bos, M. W., Dijksterhuis, A., \& Baaren, R. B. van. (2008). On the goal-dependency of unconscious thought. Journal of Experimental Social Psychology, 44, 1114-1120.

Burke, L. A., Miller, \& M. K. (1999). Taking the mystery out of intuitive decision making. Academy of Management Executive, 13(4), 91-99.

Campos, H. M., Parellada, F. S., Valenzuela, F. A. A., \& Rubio, A. M. (2015). Strategic decision-making speed in new technology based firms. Revista de Aadministração e Inovação, São Paulo, 12(2), 130-152.

Cannella, A. A. Jr., \& Holcomb, T. R. (2005). A multi-level analysis of the upper-echelons model. Multi-level Issues in Strategy and Methods Research in Multi-level Issues, 4, 197-237.

Carmeli, A., \& Schaubroeck, J. (2006). Top management team behavioral integration, decision quality, and organizational decline. The Leadership Quarterly, 17, 441-453.

Child, J. (1972). Organizational structure, environment and performance: The role of strategic choice. Sociology, 6(1), 122.

Cingöz, A. (2018). Örgüt yapıları açısından yönetim. A. Akdemir (Ed.), Örgütlerin yönetimi: Kavramsal-kuramsal, tematik ve kurumsal açılardan yönetim (s. 143-161), İstanbul: Beta Yayınları.

Cohen, J. (1988). Statistical power analysis for the behavioral sciences. Mahwah, NJ: Lawrence Erlbaum.

Dayan, M., \& Elbanna, S. (2011). Antecedents of team intuition and its impact on the success of new product development projects. Journal of Product Innovation Management, 28(1), 159-174.

Demir, B. (2015). Üst yönetimin karakteristik özelliklerinin büyüme stratejisine etkisi: üst yönetimin stratejik karar sürecinin aracılık etkisi. İstanbul Arel Üniversitesi Sosyal Bilimler Enstitüsü İşletme Yönetimi Anabilim Dalı, Yayınlanmamış Doktora Tezi, İstanbul.

Demir, B., \& Wolf, A. (2017). Üst yönetimin karakteristik özelliklerinin büyüme stratejine etkisi: Üst yönetimin stratejik karar sürecinin aracılık etkisi. Social Sciences Research Journal, 6(3), 173-198.

Driesch, T. von den, Costa, Maika, E. S., Flatten, T. C., \& Brettel, M. (2015). How CEO experience, personality, and network affect firms' dynamic capabilities. European Management Journal, 33, 245-256.

Duggan, W., \& Mason, M. (2011). Strategic intuition. M. Sinclair (Ed.), Handbook of intuition research, Glos, England: Edward Elgar Publishing Limited.

Edelman, G. (2004). Wider than the sky. New Haven, CT: Yale University Press.

Eflatun, (2017). Socrates'in savunması (Çeviren: Murat Demir). Ankara: Nilüfer Yayıncılık.

Eisenhardt, K. M. (1989). Making fast strategic decisions in high-velocity environments. Academy of Management Journal, 32, 543-576.

Eisenhardt, K., \& Bourgeois, L. (1988). Politics of strategic decision making in high-velocity environments: Toward a midrange theory. The Academy of Management Journal, 31(4), 737-770.

Elbanna, S., \& Child, J. (2007). The influence of decision, environmental and firm characteristics on the rationality of strategic decision making. Journal of Management Studies, 44, 561-591.

Elbanna, S., Child, J., \& Dayan M. (2013). A model of antecedents and consequences of intuition in strategic decisionmaking: Evidence from Egypt. Long Range Planning, 46(1-2), 149-176.

Elbanna, S., \& Fadol, Y. (2016). The role of context in intuitive decision-making. Journal of Management \& Organization, 1(5), 1-20.

Emmanuel, C., Harris, E., \& Komakech, S. (2010). Towards a better understanding of capital investment decisions. Journal of Accounting \& Organizational Change, 6(4), 477-504.

Eren, E., Aren, S., \& Alpkan, L. (2000). İşletmelerde stratejik yönetim faaliyetlerini değerlendirme araştırması. Doğuş Üniversitesi Dergisi, 1(1), 96-123.

Ferreira, P., Raisch, S., \& Klarner, P. (2014). Staying agile in the saddle: CEO tenure, TMT change, and organizational ambidexterity. Paper presented at the Annual Meeting of the Academy of Management, Philadelphia.

Fornell, C., \& Larcker, D. F. (1981). Evaluating structural equation models with unobservable variables and measurement error. Journal of Marketing Research, 18(1), 39-50.

Francioni, B., Musso, F., \& Cioppi, M. (2015). Decision-maker characteristics and international decisions for SMEs. Management Decision, 53(10), 2226-2249.

Frederick, S. (2005). Cognitive reflection and decision making. Journal of Economic Perspectives, 19(4), $25-42$. 
Fredrickson, J. W. (1984). The comprehensiveness of strategic decision processes: extension, observation, future decisions. Academy of Management Journal, 27, 445-466.

Goll, I., \& Rasheed, A. A. (1997). Rational decision-making and firm performance: The moderating role of environment. Strategic Management Journal, 18(7), 583-591.

Gordon, B., \& Berger, L. (2003). Intelligent memory. New York, NY: Viking.

Goubko, M. V., \& Mishin, P. (2008). Optimal hierarchies in firms: A theoretical model. Proceedings of the 17th World Congress The International Federation of Automatic Control, 6-11 July 2008, Seul, Korea.

Gu, J., \& Xie, F. (2009). The empirical research on the domain knowledge factors Influencing the effectiveness of intuition in decision making. 2009 Second International Symposium on Knowledge Acquisition and Modeling Knowledge Acquisition and Modeling, 1, 296-299.

Hair, J. F., Black, W. C., Babin, B. J., Anderson, R. E., \& Tatham, R. L. (2006). Multivariate data analysis. Upper Saddle River, NJ: Pearson Prentice Hall.

Hair, J. F., Tomas, G., Hult, M., Ringle, C. M., \& Sarstedt, M. (2014). A primer on partial least square structural equations modeling (PLS-SEM). Los Angeles: Sage.

Hall, D. J., \& Saias, M. A. (1980). Strategy follows structure! Strategic Management Journal, 1(2), 149-163.

Hambrick, D. C., \& Fukutomi, G. D. S. (1991). The seasons of CEO's tenure. The Academy of Management Review, 16(4), 719-742.

Hambrick, D. C., \& Mason, P. A., (1984). Upper echelons: The organization as a reflection of its top managers. Academy of Management Review, 9(2), 193-206.

Hannan, M., \& Freeman, J. (1977). The population ecology of organizations. American Journal of Sociology, 82, $929-964$.

Harrison, E. F. (1999). Managerial decision making. Boston: Houghton Mifflin Harcourt.

Henseler, J., Ringle, C. M., \& Sarstedt, M. (2015). A new criterion for assessing discriminant validity in varience-based structural equation modelling. Journal of the Academy of Marketing Science, 43, 115-135.

Judge, W. Q., \& Miller, A. (1991). Antecedents and outcomes of decision speed in differential environmental context. Academy of Management Journal, 34, 449-463.

Karabacak, G. (2010). İşgören kişilik tiplerinin iş stresi üzerine etkisi. Dokuz Eylül Üniversitesi Sosyal Bilimler Enstitüsü İşletme Anabilim Dalı, Yayınlanmamış Yüksek Lisans Tezi, İzmir.

Kaufmann, L., Meschnig, G., \& Reimann, F. (2014). Rational and intuitive decision-making in sourcing teams: Effects on decision outcomes. Journal of Purchasing \& Supply Management, 20, 104-112.

Khandwalla, P. N. (1977). Design of organizations. New York: Harcourt Brace Jovanovic.

Khatri, N., \& Ng, H. A. (2000). The role of intuition in strategic decision making. Human Relations, 53(1), 57-86.

Kılıç, (2016). Cronbach'ın alfa güvenirlik katsayısı. Journal of Mood Disorders, 6(1), 47-48.

Kotey, B., \& Folker, C. (2007). Employee training in SMEs: Effect of size and firm type-family and nonfamily. Journal of Small Business Management, 45, 214-238.

Köz, ì. (2005). Sezgi'nin bilgideki yeri ve önemi. Kelam Araştırmaları, 3(1), 23-40.

Lufityanto, G., Donkin, C., \& Pearson, J. (2016). Measuring intuition: Nonconscious emotional information boosts decision accuracy and confidence. Psychological Science, 27(5), 622-634.

Lechner, C., \& Gudmundsson, V. (2014). Entrepreneurial orientation, firm strategy and small firm performance. International Small Business Journal, 32(1), 36-60.

March, J. G., \& Simon, H. A. (1958). Organizations. New York: Wiley.

Mehrotra, R., \& Gopalan, R. (2017). Factors influencing strategic decision-making processes for the oil/gas industries of UAE-A study. International Journal of Marketing \& Financial Management, 5(1), 62-69.

Miller, D., Droge, C., \& Toulouse, J. M. (1986). Chief executive personality and corporate strategy and structure in small firms. Management Science, 32(11), 1389-1409.

Mintzberg, H. (2015). Örgütler ve yapıları. Ankara: Nobel Akademik Yayıncılık.

Mitchell, J. R., Shepherd, D. A., \& Sharfman, M. P. (2011). Erratic strategic decisions: When and why managers are inconsistent in strategic decision making. Strategic Management Journal, 32, 683-704.

Nooraie, M. (2012). Factors influencing strategic decision-making processes. International Journal of Academic Research in Business and Social Sciences, 2(7), 405-429. 
Okoli, J. O., Weller, G., \& Watt, J. (2016). Information processing and intuitive decision-making on the fireground: Towards a model of expert intuition. Cognition, Technology \& Work, 18(1), 89-103.

Okoli, J., \& Watt, J. (2018). Crisis decision-making: The overlap between intuitive and analytical strategies. Management Decision, 56(5), 1122-1134.

Öktem, Ü. (2000). Descartes, Kant, Bergson ve Husserl'de sezgi. Ankara Üniversitesi Dil ve Tarih-Coğrafya Fakültesi Dergisi, 40(1-2), 159-188.

Özmen, Ö. T., Özer, P. S., \& Saatçioğlu, Ö. Y. (2005). Akademisyenlerde örgütsel ve mesleki bağlılığın incelenmesine ilişkin bir örnek araştırma. Dokuz Eylül Üniversitesi İşletme Fakültesi dergisi, 6(2), 1-14.

Papadakis, V. M., \& Barwise, P. (2002). How much do CEOs and top managers matter in strategic decision-making? British Journal of Management, 13, 83-95.

Papadakis, V. M., Lioukas, S., \& Chambers, D. (1998). Stratejic decision-making process: The role of management and context. Strategic Management Journal, 19, 115-147.

Papulova, Z., Gazova, A. (2016). Role of strategic analysis in strategic decision-making. Procedia Economics and Finance, 39, 571-579.

Parayitam, S., \& Pepenhausen, C. (2018). Strategic decision-making: The effects of cooperative conflict management, agreement-seeking behavior and competence-based trust on decision outcomes. Management Research Review, 41(1), 2-28.

Patterson, R. E., Pierce, B. J., Boydstun, A. S., Ramsey, L. M., Shannan, J., Tripp, L., \& Bell, H. (2013). Training intuitive decision making in a simulated real-world environment. Human Factors, 55(2), 333-345.

Pretz, J. E. (2011). Types of intuition: Inferential and holistic. M. Sinclair (Ed.). Handbook of Intuition Research. Glos, Ingiltere: Edward Elgar Publishing Limited.

Priem, R. L., Rasheed, A. M. A., \& Kotulic, A. G. (1995). Rationality in strategic decision processes, environmental dynamism and firm performance. Journal of Management, 21(5), 913-929.

Quinn, R. J. (2004). Investigating probabilistic intuitions. Teaching Statistics, 26(2), 86-88.

Rahman, O, Wong, K. K., \& Yu, H. (2016). The effects of mall personality and fashion orientation on shopping value and mall patronage intension. Journal of Retailing and Consumer Services, 28, 155-164.

Ringle, C. M., Wende, S., \& Becker, J. M. (2015). SmartPLS 3. www.smartpls.com (Erişim Tarihi: 29.11.2019).

Sarstedt, M., Ringle, C. M., \& Hair, J. F. (2017). Partial least squares structural equation modelling. C. Homburg, M. Klarmann, \& A. Vomberg (Eds.), Handbook of market research, Heidelberg: Springer.

Sarvan, F., Arıcı, E. D., Özen, J., Özdemir, B., \& İçigen, E. T. (2003). On stratejik yönetim okulu: Biçimleşme okulunun bütünleştirici çerçevesi. Akdeniz Üniversitesi i.i.B.F. Dergisi, 6, 73-122.

Shepherd, N. (2014). An empirical examination of the strategic decision-making process, the relationship between context, process, and outcomes. Aston Universitesi, Birmingham, Yayınlanmamış Doktora Tezi, İngiltere.

Shepherd, N. G., \& Rudd, J. M. (2014). The influence of context on the strategic decision-making process: A review of the literature. International Journal of Management Reviews, 16, 340-364.

Sinclair, M. (2011). Conceptualizing intuition. M. Sinclair (Ed.), Handbook of intuition research, Glos, İngiltere: Edward Elgar Publishing Limited.

Slater, S., Paliwoda, S., \& Slater, J. (2007). Ethnicity and decision making for internationalisation. Management Decision, 45, 1622-1635.

Sur, M. (1986). Hayek'in sosyal bilim yöntemlerine yaklaşımı: Bilimselcilik ve sosyal bilimler. Ankara Üniversitesi Siyasal Bilgiler Fakültesi Dergisi, 41(1-4), 329-355.

Şimşek, Z., Veiga, J. F., Lubatkin, M. H., \& Dino, R. N. (2005). Modeling the multilevel determinants of top management team behavioral integration. Academy of Management Journal, 48, 69-84.

Tekin, M., \& Çiçek, E. (2005). İşletmelerde rekabet üstünlüğü sağlamada farklı bir yaklaşım: Değer temelli pazarlama. İstanbul Ticaret Üniversitesi V. Ulusal Üretim Araştırmaları Sempozyumu, 25-27 Kasım, İstanbul, 63-68.

Terjesen, S., \& Szerb, L. (2008). Dice thrown from the beginning? An empirical investigation of determinants of firm level growth expectations. Estudios de Economía, 35(2), 153-178.

Tura, S. M. (1996). Metapsikoloji ve fenomenoloji. Toplum ve Bilim, 70, 261-268.

Türk Dil Kurumu, Güncel Türkçe sözlük, https://www.tdk.gov.tr/index.php?option=com_gts\&arama= sezgi (Erişim Tarihi: 29.12.2019). 
Tversky, A., \& Kahneman, D. (1974). Judgment under uncertainty: Heuristics and biases. Science New Series, 185(4157), 1124-1131.

Tyler, B. B., \& Steensma, H. K. (1998). The effects of executives' experiences and perceptions on their assessment of potential technological alliances. Journal of Business Research, 19(10), 939-965.

Ürü, F. O., Çalışkan, C. S., Atan, Ö., \& Aksu, M. (2011). How much entrepreneurial characteristics matter in strategic decision-making? Procedia Social and Behavioral Sciences, 24, 538-562.

Ürü Sanı, F. O., Wolff, R. A., \& Demir, B. (2016). Çevresel determinizmin stratejik karar alma sürecindeki rolü. Eurasian Academy of Sciences Social Sciences Journal, 1(1), 444-465.

Ürü Sanı, F. O. (2018a). Karar açısından yönetim. A. Akdemir (Ed.), Örgütlerin yönetimi (s.163-217), İstanbul: Beta Basım Yayım.

Ürü Sanı, F. O. (2018b). Stratejik açıdan yönetim. A. Akdemir (Ed.), Örgütlerin yönetimi (s. 401-453), İstanbul: Beta Basım Yayım.

Wally, S., \& Baum, J.R. (1994). Personal and structural determinants of the pace of strategic decision making. Academy of Management Journal, 37(4), 932-956.

Yaşar, O. (2016). Davranışsal karar verme, düşünme, problem çözme. Ankara: Detay Yayıncılık. 
This Page Intentionally Left Blank 